\title{
MAde IN God's IMAGE NORTH AND SOUTH OF THE 49Th Parallel: END-OF-Life ETHICAL ASSUMPTIONS and Substantive Due Process
}

\author{
PATRICK CLARK ${ }^{*}$
}

\section{INTRODUCTION}

In 1997, the U.S. Supreme Court considered one of the most profound and moral legal issues in its landmark decision-physician-assisted suicide. ${ }^{1}$ In its decision, Washington v. Glucksberg, the Court held that the Constitution did not protect the right to physician-assisted suicide. ${ }^{2}$ The Supreme Court refused to overturn Washington's physician-assisted suicide ban, but overshadowed by its holdings were the plaintiffs, who made an appeal for their lives. ${ }^{3}$ Among those plaintiffs were three terminally ill patients who banded together in their final moments in an effort to strike down the physician-assisted suicide ban. They tried to clear a path for other similarly situated patients to control their final moments on their own terms. ${ }^{4}$ Although the patients litigated under pseudonyms, the substance of their realities was real. ${ }^{5}$

The first patient was a 69 -year-old physician and a suffering cancer patient who was bedridden for seven months during the pendency of trial. ${ }^{6}$ She died before the district court issued its decision. ${ }^{7}$ The second patient was a 44-year-old artist who was partially blind and suffered from AIDS. ${ }^{8}$ He also died before the district court issued its decision. ${ }^{9}$ The third patient was a 69 -year-old patient who suffered from chronic obstructive pulmonary disease and was connected to an oxygen tank at all times. ${ }^{10}$ Although he was fortunate enough to hear the district court's original denial of his case, he died before the Ninth Circuit Court of Appeals heard his appeal. ${ }^{11}$

The plaintiffs lived their lives without the legal right to die. They lived in

* J.D., 2020, Indiana University Robert H. McKinney School of Law; B.A. 2017, Butler University, Indianapolis, Indiana. I would like to thank Professor John Hill, as my faculty advisor, for his insightful critiques and guidance throughout the writing process. I would also like to thank the editors of the Indiana International and Comparative Law Review for their feedback and edits. I am sincerely grateful and appreciative for my wife, Afton Clark, and her never ending love and support.

1. 521 U.S. 702 (1997).

2. $I d$.

3. Id. at 735 .

4. Id. at 707 .

5. $I d$.

6. Compassion in Dying v. Washington, 49 F.3d 586, 588 (9th Cir. 1995).

7. $I d$.

8. $I d$.

9. $I d$.

10. Id.

11. Id. 
agony of their eventual demise. Through it all, they were not afforded the opportunity to take matters into their own hands and decide their final moments. The Washington government disregarded the idea that individuals should have that choice and asserted control over an intimate and personal decision. This Note argues that undergirding the ban's legitimacy and the Supreme Court's reasoning are historically religious pretexts for its hegemony over the terminally ill's final moments.

During the sixteenth century, Protestants of England and Catholics of France, the dominant religious expressions in each country, began to transport their dogmas to the "New World." Protestant Puritans' theology was deeply rooted into the full range of American colonial experience, and the Roman Catholic theology was a fecund influencer in Canadian colonies and provinces. Religious adherence was strictly enforced, often through force of "secular" law, as enshrined in common law exported from the "old country" or homegrown legislation and judicial interpretation of such in burgeoning communities in the New World. Independent nations emerge, but many of their laws, including end-of-life issues, retained their original theological underpinnings.

To this day, forty states still maintain their bans on physician-assisted suicide, but those state legislatures are continuing to consider repeals. ${ }^{12}$ Reconsideration of a constitutionally recognized right to physician-assisted suicide has led to a grinding halt where inconsistencies in end-of-life decisions still remain good law. This Note argues that constitutional analyses distinguishing the right to refuse medical treatment and physician-assisted suicide are inconsistent and they are held together by untenable religious justification supporting physician-assisted suicide bans and treating the practices differently. This Note examines how religious beliefs influenced and continue to inform end-of-life healthcare legislation in the United States and Canada.

This Note chronicles the legacy of Puritan and Catholic beliefs in laws related to end-of-life decision-making in the United States and Canada. Part 1 discusses the historical religious philosophy transfer from England and France to the United States and Canada, respectively, identifying foundational religious beliefs regarding death and laws relating thereto. Part 2 covers two end-of-life issues - the right to refuse medical treatment and physician-assisted suicide-identifying the religious beliefs underpinning the pervasive social practices and legal policies. Part 3 compares and contrasts the right to refuse medical treatment and physician-assisted suicide in the United States and Canada, as well as tracking the religious justifications for constitutional interpretations in the United States. Part 4 provides recommended improvements to U.S. constitutional analysis of the Substantive Due Process Clause. Finally, Part 5 concludes with a summary of the comparative constitutional analysis.

12. See generally Take Action in Your State, DeAth with Dignity, https://www. deathwithdignity.org/take-action/ (last visited May 2, 2020) [https://perma.cc/9BCE-6GH3] [hereinafter DEATH WITH Dignity] for an updated live list of states that have passed physicianassisted suicide legislation. 


\section{EUROPEAN COLONIZERS ON DEATH AND SUICIDE}

This part analyzes foundational religious beliefs of death and suicide. It then tracks such beliefs throughout history and their manifestation in legislation from the New World to their contemporary versions - the United States and Canada. This part also compares and contrasts the United States and Canada in their beliefs.

\section{A. Foundational Beliefs}

Although the Bible never specifically condemns suicide, ${ }^{13}$ a general view against suicide has been inferred from the Sixth Commandment: ${ }^{14}$ "Thou shalt not kill." ${ }^{15}$ Numerous biblical references condemn the general impact of suicide because suicide rejects God's sovereignty by taking life on the suicide committer's terms: "In whose hand is the soul of every living thing, and the breath of all mankind."16 Rejecting God's sovereignty also rejects his image: "And God said, 'Let us make man in our image' . . . So God created man in his own image, in the image of God created he him; male and female created he them." ${ }^{17}$ Suicide also rejects other aspects of God's will (i.e., the sanctity of human life $^{18}$ and injury to others ${ }^{19}$ ) because followers of God are asked to suffer together with Christ, ${ }^{20}$ with such earthly suffering incomparable to the glory waiting in the afterlife. ${ }^{21}$ God chooses who dies: "And as it is appointed unto men once to die, but after this the judgment." ${ }^{22}$ Physical death is a consequence of $\sin ,{ }^{23}$ and the universality of death proves the universality of $\sin ^{24}$

The early Christian Church condemned suicide, and it was similarly banned throughout Europe. ${ }^{25}$ Christian theologians oppose suicide for several reasons. ${ }^{26}$ As noted above, the Bible, under the Sixth Commandment, rejects killing anyone, including suicide. ${ }^{27}$ Suicide is prohibited under the Sixth Commandment, and Christian theologians have reasoned that human life is God's property, and

13. Wilbur Larremore, Suicide and the Law, 17 HARV. L. REV. 331, 332 (1904).

14. Matthew P. Previn, Assisted Suicide and Religion: Conflicting Conceptions of the Sanctity of Human Life, 84 GEO. L.J. 589, 595 (Feb. 1996).

15. Exodus 20:13.

16. Job $12: 10$.

17. Genesis 1:26-27.

18. Genesis 9:5-6.

19. Ephesians 5:29.

20. Romans 8:17.

21. Romans 8:18-21.

22. Hebrews 9:27.

23. Genesis 3:19.

24. Romans 5:12-14.

25. Exodus 20:13; Previn, supra note 14, at 595.

26. Previn, supra note 14, at 595.

27. Id. 
therefore, only God has the right to take it. ${ }^{28}$ God has sovereignty over the life $\mathrm{He}$ created because He created human life in His image. ${ }^{29}$ Because God has sovereignty over Himself, He casts sovereignty over those who He creates, establishing human life as God's property.

God claims ownership over human life, and He values the sanctity of life because such value derives from Himself. ${ }^{30}$ Hence, suicide rejects both God's sovereignty and value in life ${ }^{31}$ therefore, a person who commits suicide or physician-assisted suicide attempts to usurp God's ownership of human life. ${ }^{32}$ Accordingly, a death must occur naturally on God's terms, without unnatural assistance or preemptively by the individual. ${ }^{33}$ For these reasons, most mainstream Christian denominations hold that suicide and physician-assisted suicide reject God's sovereignty. ${ }^{34}$

The writings of St. Thomas Aquinas, an influential philosopher on theology and a proponent of the Western classic canon in the Middle Ages, profoundly influenced Western Christianity. ${ }^{35}$ Aquinas believed that suicide violated Christian tenets for three reasons:

first, suicide is contrary to the natural inclination toward self-preservation and to charity whereby everyone should love oneself; second, because each person is a part of a community, the killing of oneself involves injury to that community; and third, suicide is a violation of God's rights over man as man's Creator. ${ }^{36}$

These beliefs appear to complement the previously referenced Bible verses that condemn (even if indirectly) suicide.

\section{B. British Common Law}

England's common law opposed suicide. ${ }^{37}$ Thomas Cranmer (1489-1556), Archbishop of Canterbury and an influential figure in shaping the Church of England, said that suicide was "cursed of God, and damned forever."'138 In 1594,

28. Id.

29. Genesis 1:26-27.

30. Genesis 9:5-6; Previn, supra note 14, at 595.

31. Ephesians 5:29.

32. Matt Slick, What Does the Bible Say About Euthanasia?, Christian APOLOGETICS AND RESEARCH MinISTRY, https://carm.org/bible-say-about-euthanasia (last visited Jan. 9, 2020) [https://perma.cc/2C9Y-LXV4].

33. Id.

34. See infra Part I.4.

35. Thomas J. Marzen et al., Suicide: A Constitutional Right?, 24 DuQ. L.R. 1, 29 (1985).

36. Id.

37. Neil M. Gorsuch, The Right to Assisted Suicide and Euthanasia, 23 HARv. J.L. \& PuB. POL'y 599, 630 (2000); Larremore, supra note 13, at 332.

38. Marzen et al., supra note 35, at 32 (quoting S. Sprott, The English Debate on Suicide from Donne to Hume 3 (1961)). 
John King (who later became Bishop of London) taught that Scripture prohibited suicide, and King agreed with Aquinas's views on suicide. ${ }^{39}$ Beyond these august and influential opinions, clergy widely taught that suicide was "diabolical." John Sym, an Anglican clergyman with Puritan inclinations, ${ }^{41}$ proclaimed that the devil and its persuasions would convince people to commit suicide. ${ }^{42}$ Many other prominent Puritans vigorously opposed suicide. ${ }^{43}$

\section{Religious Influences in the United States}

\section{Puritans}

Puritans escaping religious persecution found shelter in the Thirteen Colonies ${ }^{44}$ populating them with people "who intended to create an inherently spiritual nation, envisioning it as a land of purity and spiritually righteous people. ${ }^{\circ 5}$ As a result, individuals, cultural norms, and legislative theory and practice often conformed to Protestant-Puritan beliefs, and such Puritan-social DNA lurks in U.S. culture to this day. ${ }^{46}$ Consider the following, which explains Puritan influence on America's culture and founding:

A self-selection process, in which especially devout Protestants left England to settle in the New World, may help explain the persistent prominence of religion in American life. While the early English settlers were followed by others pursuing economic goals, it was arguably the devout Protestants who laid the foundation of American culture. Because religiously devout settlers got in on the "ground-floor" of a new society, they seem to have exerted a sizeable influence over what eventually became the American creed. ${ }^{47}$

Although Puritans immigrated to the New World to escape England's religious persecution, Puritans arrived in settlements that were instituted for

39. Id. (citing S. Sprott, The English Debate on Suicide from Donne to Hume 3, 5 (1961)).

40. Michael MacDonald, The Secularization of Suicide in England 1660-1800, 111 PAST \& Present, May 1986, at 50, 54.

41. Marzen et al., supra note 35, at 32 (citing S. Sprott, The English Debate on Suicide form Donne to Hume 31 (1961)).

42. MacDonald, supra note 40 (quoting Hugh Latimer, The Works of Hugh Latimer 435 (George Elwes Corrie ed., 1845)).

43. S. Sprott, The English Debate on Suicide from Donne to Hume (1961); Marzen et al., supra note 35 , at 32 .

44. Eric Luis Uhlmann et al., Implicit Puritanism in American Moral Cognition, $47 \mathrm{~J}$. ExPerimental Soc. Psychol. 1, 313 (Oct. 21, 2010).

45. Id. at 312 .

46. Id.

47. Id. at 313 (citation omitted). 
economic purposes. ${ }^{48}$ The Puritan belief system strongly influenced contemporary American economic values, such as individualism. ${ }^{49}$ Individualism was often at odds with providing for the common good and limiting one's self-interest. ${ }^{50}$ Puritans permitted many to seek out their own careers, which was very individualistic, but the self-interested nature was justified as serving the common good because it served "the good of the self." ${ }^{51}$ Many with greater wealth were expected to pursue a greater share of charity and help those who were impoverished, but the economically disadvantaged were never entitled to aid because such aid was thought to disincentivize the impoverished from seeking out their own career. ${ }^{52}$

Puritans adhered to the doctrine of predestination, which is the belief that God preordains an individual's salvation (eternal life or damnation after death) before the individual dies. ${ }^{53}$ Individuals cannot attain salvation of their own volition because the outcome is predetermined. ${ }^{54}$ Adam's original sin of defying God caused the innate sin of man which prevents people from pursuing their own salvation and requires that they must die. ${ }^{55}$ Therefore, redemption can be achieved only through God's arbitrary will. ${ }^{56}$

Although the principle of predestination dictates the outcome of an individual (i.e., God knows the outcome of who will and will not receive his redemption), individuals may still pursue their own vocation as long as it serves God. ${ }^{57}$ The principles of predestination and individualism seem at odds with each other - God knows what will happen, and the individual freely pursues his or her own career. ${ }^{58}$ This seeming contradiction can be reconciled in that God, who knows the outcome of actions and predetermines salvation, may permit people to freely take those actions (e.g., freely choosing a vocation).

48. Arlin M. Adams \& Charles J. Emmerich, A Heritage of Religious Liberty, 137 U. PA. L. REV. 1559, 1562 (May 1989).

49. Donald E. Frey, Individualist Economic Values and Self-Interest: The Problem in the Puritan Ethic, 17 J. Bus. EThics 1573, 1573 (Oct. 1998). Individualism means "[t]he conception that all values, rights, and duties originate in individuals." Merriam-Webster, https://www.merriamwebster.com/dictionary/individualism (last visited Feb. 1, 2020) [https://perma.cc/QYF9-H4SG].

50. Id. at 1573-74.

51. Id. at 1575 .

52. Id. at 1577.

53. Diplomová Práce, The Puritan View of Death: Attitudes Toward Death and Dying in Puritan New England, (Jan. 2011) at 1, 7, https://is.cuni.cz/webapps/zzp/download/120013132 [https://perma.cc/EM9W-K2LZ].

54. Id.

55. Id. at 8,38 .

56. Id. at 8 .

57. Frey, supra note 49, at 1575 (quoting William Perkins, Of the Vocations or Callings of Man, in Puritan Political Ideas 1558-1794 (E.S. Morgan ed., 1965).

58. Some seemingly contradictory Puritan beliefs may co-exist, but other principal-conflicts demonstrate the inner-turmoil that Puritans had to rectify. See generally Práce, supra note 53, at $27-28$. 
Individuals had choice in the dying process because death was in the individual's hands and the hands of the individual's family and friends. ${ }^{59}$ The Puritans' guiding principle in the afterlife was "saving grace"-a level of assurance that would permit someone to move into the afterlife. ${ }^{60}$ However, uncertainty of an individual's outcome after death was at conflict with the assurance of life after death. ${ }^{61}$ In addition, death was "both [a] punishment and [a] reward" ${ }^{\prime 2}$ since death was a penalty for sin, and it meant returning to the Lord, respectively. ${ }^{63}$ Christians were uncertain of the afterlife because of conflicting paradigms: (1) predetermination and individualism and (2) death as punishment and reward led to uncertainty conceptions about death. Christians feared more the possible "terrors of hell" that might await them on the other side, than the physical pain of dying - a fear that would never lead them to support or approve of assisted suicide. ${ }^{64}$

\section{Methodists}

Methodists comprised the largest religious community in the United States in the nineteenth century. ${ }^{65}$ Methodism stressed dying a "good death," meaning those who were near-death overcame fear and danger in their final moments of passing. ${ }^{66}$ Prayer and the presence of a minister assisted dying Methodists to achieve a good death. ${ }^{67}$ The event of death was a community affair that included bystanders, immediate relatives, local minister or elder, friends, and neighbors, all of whom assisted the dying person's passing in prayer. ${ }^{68}$

"On the one hand, the deathbed presented the dying with the final opportunity for eternal salvation, through repentance for sins and forgiveness. On the other hand, the last article of life was a test and final temptation." ${ }^{\circ 9}$ This coincides with the general views of death and suicide in the Bible. ${ }^{70} \mathrm{~A}$ dying individual was

59. David E. Stannard, Death and Dying in Puritan New England, 78 AM. Hist. Rev. 1305, 1308 (Dec. 1973), https://www.jstor.org/stable/1854094 [https://perma.cc/35DM-8TA8].

60. Id. at 1310. "The Puritans were gripped individually and collectively by an intense and unremitting fear of death, while simultaneously clinging to the traditional Christian rhetoric of viewing death as a release and relief for the earthbound soul." $I d$. at 1315.

61. Id. at 1312 .

62. Id. at 1313.

63. Práce, supra note 53, at 18.

64. Ian Bowdiggin, A Concise History of Euthanasia: Life, Death, God, and MEDICINE 38 (2005).

65. Shai Lavi, Euthanasia and the Changing Ethics of the Deathbed: A Study in Historical Jurisprudence, 4 THEORETICAL INQ. L. 729, 734 (July 2003).

66. Id. at 735 .

67. Id.

68. Id. at 734 .

69. Id. at 735 .

70. See supra Part I.A. 
tempted with guilt for his or her sins, the pride of successes, or desire for worldly things. ${ }^{71}$ Overcoming or succumbing to temptation would have led to eliminating committed sins or cancelling out good deeds, respectively. ${ }^{72}$ Methodist ministers and their rituals helped to overcome temptations, but even unconscious dying individuals did not need free will to achieve a good death. ${ }^{73}$ Nineteenth-century Methodists likely prioritized a good death over an individual's autonomy because medically hastening death would have "robbed the dying of the opportunity to face his or her death and overcome it." "74

\section{Other Denominations}

Christian theologians believe "human suffering has value." 75 Similar to the Methodists' view in overcoming suffering and the general view of the Bible, Christian theologians disagree with killing suffering patients because individuals are rewarded for suffering with the divine rewards in the afterlife. ${ }^{76}$ Christian theologians also maintained a view of the sanctity of life:

a man who destroys his own life has committed a crime similar both in kind and magnitude to that of an ordinary murderer, and they at the same time gave a new character to death by their doctrines concerning its penal nature and concerning the future destinies of the soul. ${ }^{77}$

Pope John Paul II rejected euthanasia and declared that modern culture mistakenly "fails to perceive any meaning or value in suffering, but rather considers suffering the epitome of evil, to be eliminated at all costs . . . The theological underpinning to this position is that Christians should bear their suffering just as Christ bore the cross to save humankind from evil." 78 The Vatican's Declaration on Euthanasia in 1980 rejected euthanasia as "a question of the violation of the divine law, an offense against the dignity of the human person, a crime against life, and an attack on humanity." 79 The Catholic Church stresses that a cause of death should be natural; for example, an individual who had emphysema was concluded to die from the emphysema and not the removal

71. Lavi, supra note 65 , at 735.

72. Id.

73. Id. at 735-36. Methodists' belief in death transitioned over the nineteenth-century from the final hour of death to overcome death which was defined as a metaphor to mean that when one sins, the entire human condition has been corrupted and therefore, died. Id. at 378 .

74. Id. at 742 .

75. Previn, supra note 14, at 596.

76. Id.

77. Larremore, supra note 13, at 331 (quoting W.E.H. LECKY, HISTORY OF EUROPEAN Morals 45 (1869)).

78. Previn, supra note 14, at 596 (citation omitted).

79. Jerome Hamer, Sacred Congregation for the Doctrine of the Faith: Declaration on Euthanasia, VATICAN (May 5, 1980), http://www.vatican.va/roman_curia/congregations/cfaith/ documents/rc_con_cfaith_doc_19800505_euthanasia_en.html [https://perma.cc/ECL6-TDMW]. 
of the ventilator. ${ }^{80}$ Therefore, the dying individual would die from the underlying causes of the disease, achieving the natural death as opposed to hastening death with the intervention of unnatural substances. ${ }^{81}$

Most Protestant denominations tend to reject physician-assisted suicide. ${ }^{82}$ Generally, Anglicans and Episcopalians (including Lutherans) have stated that it is morally wrong to commit physician-assisted suicide and to destroy life created in the image of God. ${ }^{83}$ The Southern Baptist Church expresses disapproval of both suicide and assisted-suicide, reasoning that in God creating human life and declaring life to be sacred, God decrees life's sacredness from conception until natural death. ${ }^{84}$ Assemblies of God views physician-assisted suicide as a "mistaken, deceptive and evil philosophy." "Assemblies of God identifies three principals as derived from the Bible: "(1) proclaim humankind's dignity as God's sovereign creation, (2) reassert God's authority over life from conception to death, and (3) affirm meaning and hope for suffering humanity."${ }^{" 86}$

\section{Religious Influences in Canada}

From 1534 to 1536 Jacques Cartier voyaged to France three times, with religion as the initial motivation but economic motivations were more prominent. ${ }^{87}$ After Cartier's fourth visit, he established a "short-lived colony." ${ }^{" 88}$ Cartier failed to bring back anything of value, so France turned its attention away from Canada. ${ }^{89}$ However, French colonists were interested in the region's

80. Robert J. McClory, Faithful Departures: How Catholics Face the End of Life, US CATHOLIC, http://www.uscatholic.org/church/2008/07/faithful-departures-how-catholics-face-endlife [https://perma.cc/6HJJ-JDAB].

81. Id.

82. Religious Perspectives on Euthanasia, SAINT JosePH'S UnIV., https://sites.sju.edu/ icb/religious-perspectives-on-euthanasia/ [https://perma.cc/7MCK-SGML].

83. Id. Presbyterians, for example, are warmer to physician-assisted suicide than other denominations: "Decisions to hasten death may be understandable as a last resort when all connection to one's community has been or will be lost and medical pain management is no longer effective." Abiding Presence: Living Faithfully in End of Life Decisions, PRESBYTERIAN Mission (2016), https://www.presbyterianmission.org/wp-content/uploads/End-of-Life-Decisions-2016ACSWP.pdf [https://perma.cc/7S7J-5DM9].

84. Resolution on Assisted Suicide, SOUTHERn BAPTIST CONVENTION (1996), http://www.sbc. net/resolutions/278 [https://perma.cc/HNL9-4J94].

85. Sanctity of Human Life: Suicide, Physician-Assisted Suicide, and Euthanasia, Assemblies of God (Aug. 9-11, 2010), https://ag.org/Beliefs/Position-Papers/Suicide-AssistedSuicide-Official-AG-Position-Paper [https://perma.cc/4SPR-E7DS].

86. Id.

87. Jacques Mathieu, New France, CANAdian EnCYClOPEDIA (Mar. 4, 2015), https://www. thecanadianencyclopedia.ca/en/article/new-france [https://perma.cc/T7PS-VY9N].

88. Id.

89. Id. 
fisheries, which later led to the onset of the fur trade and drew the French further into the continent. ${ }^{90}$ In 1608, Samuel de Champlain, the founder of New France, followed in Cartier's footsteps, and the newly found settlement was exploited for economic gains. ${ }^{91}$ Upon establishing New France, a charter was granted to the Company of New France, which established that colonists could only be Roman Catholic. ${ }^{92}$ For example, the Huguenots were prohibited from being colonists due to potential danger of religious strife within the colony that would have proved difficult to control in New France. ${ }^{93}$

Excluding the Huguenots from the colony of New France established a foothold for the Roman Catholic Church in the colony that affected the lives of everyone. ${ }^{94}$ The Church also exerted a profound influence on the New France government. ${ }^{95}$ The bishop was given a seat on the Sovereign or Superior Council, and the parish became the effective unit for local government. ${ }^{96}$ The most important leaders of the colony were the parish priest and the captain of militia. ${ }^{97}$ Early in the colony, other religions began to take root, but they did not reduce the church's influence; rather, the Church sought to maintain its dominant position for the duration of the colony. ${ }^{98}$

In the late 20th century, Canada grew to be more secular. ${ }^{99}$ Canada's secularization could be evidenced by the declining number of priests and parishioners in the Catholic Church. ${ }^{100}$ The increasing secularization of society was known as the "Quiet Revolution." 101 As a result of the intense socio-political culture change in Quebec, the Catholic Church greatly diminished in its influence over education and other social institutions. ${ }^{102}$ The population of Quebec increasingly identified themselves with French culture instead of Catholicism. ${ }^{103}$

Even though Canada is seemingly secular, Roman Catholicism remains the dominant religion in Canada. Roman Catholics maintain a strong belief against physician-assisted suicide and euthanasia. For example, the Archdiocese of

90. Id.

91. Id.

92. W.S. Wallace, Religious History of Canada, MARIANOPOLIS UNIV. (1948), http://faculty. marianopolis.edu/c.belanger/quebechistory/encyclopedia/CanadaReligiousHistory_000.htm [https://perma.cc/H24G-ZH6Z].

93. Id.

94. Id.

95. Id.

96. Id.

97. Id.

98. Id.

99. Michael D. Knowles et al., Roman Catholicism, EnCYClOPEDIA BRITANNICA (Jan. 9, 2019), https://www.britannica.com/topic/Roman-Catholicism/Roman-Catholicism-in-the-UnitedStates-and-Canada [https://perma.cc/HD8H-R3JF].

100. Id.

101. Id.

102. Id.

103. Id. 
Toronto cited Pope Francis in opposition to legislation legalizing physicianassisted suicide. ${ }^{104}$ Similarly, Canadian Bishops oppose physician-assisted suicide. ${ }^{105}$ Reasons for rejecting physician-assisted suicide are threefold: (1) life has intrinsic value and is supported by the sanctity of life, (2) God maintains sovereignty over human life and directs death, and (3) life imposes an obligation on the living to continue life. ${ }^{106}$

Canada and the United States exhibit numerous similarities in both their cultural heritage, common European history, and geographical proximity. ${ }^{107}$ However, divergent are the influences both countries' founding exhibit on their contemporary cultures. ${ }^{108}$ Although Canada was founded with religion in mind, colonizer economic motivations established a more secular culture than the United States and its heavy waves of Puritan influences. ${ }^{109}$ Contemporary differences can provide insight into the disparate underpinnings of both countries' foundings. For instance, Canadians attend church at lower rates and their politicians' rhetoric is devoid of religious references whereas U.S. citizens attend church more frequently and their politicians wed their rhetoric inexplicably to religion. ${ }^{110}$

\section{DEATH AND SUICIDE: A LEGISLATIVE HISTORY}

As religious foundational beliefs concerning death, suicide, and physiciansuicide were carried throughout U.S. and Canadian history, such beliefs manifested in each countries' respective legislation. ${ }^{111}$ Building on religious history, Part II tracks the legal status of physician-assisted suicide in the United States and Canada. This Part establishes the basis for the historical analyses in both countries' constitutions.

\section{A. United States}

Religious sentiment was pervasive throughout England. Christianity was

104. Thomas Collins, Statement from Cardinal Thomas Collins Concerning Introduction of Federal Euthanasia/Assisted Suicide Legislation, ARChDIOCESE OF TORONTO (Apr. 14, 2016), https://www.archtoronto.org/media-centre/news-archive/chancery-news/cardinal-thomas-collinseuthanasia-assisted-suicide-legislation-april-2016 [https://perma.cc/GNM4-B9A6].

105. Canadian Bishops: Keep Palliative Care Distinct from Assisted Suicide, CATHOLIC NEWS AgENCY (Aug. 11, 2018, 4:35 PM), https://www.catholicnewsagency.com/news/canadian-bishopskeep-palliative-care-distinct-from-assisted-suicide-37915 [https://perma.cc/W5QX-PCNC].

106. Euthanasia and Assisted Suicide: Urgent Questions, CATHOLIC ORG. FOR LifE AND FAMILY 3 (2005), http://www.chac.ca/resources/other_resources/euthanasia.pdf [https://perma. cc/DB4Y-E6XM].

107. Uhlmann, supra note 44 , at 315 .

108. Id.

109. Id.

110. Id.

111. See infra Part II. 
entrenched with the culture and governmental rule in England. So too was Christianity's pervasiveness of anti-suicide belief, which was embedded in English common law. ${ }^{112}$ Blackstone summarized the common law of suicide:

The law of England wisely and religiously considers that no man hath a power to destroy life, but by commission from God, the author of it; and, as the suicide is guilty of a double offense, one spiritual, in invading the prerogative of the Almighty, and rushing into his immediate presence uncalled for; the other temporal, against the king, who hath an interest in the preservation of all his subjects; the law has therefore ranked this among the highest crimes, making it a peculiar species of felony, a felony [committed] on one's self. . . But now the question follows, what punishment can human laws inflict on one who has withdrawn himself from their reach? They can only act upon what he has left behind him, his reputation and fortune; on the former, by an ignominious burial in the highway, with a stake driven through his body; on the latter by a forfeiture of all his goods and chattels to the king; hoping that his care for either his own reputation or the welfare of his family would be some motive to restrain him from so desperate and wicked an act. ${ }^{113}$

With the onset of Blackstone's affirmation of suicide in English common law, the same legal code and legal principles were brought to the American colonies. "The primary and most reliable indication of [a national] consensus is . . . the pattern of enacted laws." 114 Many of the original colonies outright adopted the English common law: Virginia, North Carolina, South Carolina, Georgia, New York, and New Hampshire. ${ }^{15}$ Similarly, a consensus among the colonies punished suicide. On October 28, 1701, William Penn stated in the Pennsylvania Charter of Privileges:

IF any person, through Temptation or Melancholy, shall destroy himself; his Estate, real and personal, shall notwithstanding descend to his Wife and Children, or Relations, as if he had died a natural Death; and if any Person shall be destroyed or killed by Casualty or Accident, there shall be no Forfeiture to the Governor by reason thereof. ${ }^{116}$

The prohibition of suicide in William Penn's Charter follows Blackstone's English prohibition, excluding the punishment of forfeiture that would affect deceased person's family.

On August 25, 1661, in Westmoreland County, Virginia, a coroner wrote of

112. Larremore, supra note 13.

113. Id.

114. Stanford v. Kentucky, 492 U.S. 361, 373 (1989).

115. Marzen et al., supra note 35, at 64-69.

116. Charter of Privileges Granted by William Penn, esq. to the Inhabitants of Pennsylvania and Territories, Oct. 28, 1701 (The Avalon Project, 2008), https://avalon.law.yale.edu/18th_ century/pa07.asp [https://perma.cc/65CR-QAZZ]. 

THE 49TH PARALLEL

a servant who drowned himself in a creek. ${ }^{117}$ Having determined it was a suicide and after a jury found of the same, the coroner wrote that "[a]ccording to our oaths \& consciences \& hath caused him to be buried at ye next cross path as ye Law Requires with a stake driven through ye middle of him in his grave hee having willfully Cast himself away." " 118 Similarly in colonial South Carolina, suicide was classified as a felony. ${ }^{119}$ South Carolina law charged the coroner to instruct the jury to investigate the circumstances of suicide: "If he died of his own felony, then to enquire of the manner, means and instrument, and circumstances concurring." "120

U.S. courts began recognizing the right to refuse medical treatment. ${ }^{121}$ In 1990, the Supreme Court affirmed the right to refuse medical treatment in a 6-3 vote. $^{122}$ In 1997, the Supreme Court reaffirmed the right to refuse medical treatment, while unanimously refusing a constitutionally protected right to physician-assisted suicide. ${ }^{123}$ States have passed laws recognizing the right to physician-assisted suicide in Maine (2019), New Jersey (2019), Hawaii (2019), Washington D.C. (2017), California (2016), Colorado (2016), Vermont (2013), Washington (2009), and Oregon (1997). ${ }^{124}$ Montana currently permits physicianassisted suicide based on a 2009 court decision. ${ }^{125}$ Numerous states are also considering proposals to legalize physician-assisted suicide. ${ }^{126}$

\section{B. Canada}

In 1759, Britain took control of New France and planned to enforce adherence to the Anglican Church. ${ }^{127}$ Instead, Britain, fearing a similar rebuke from the 13 Colonies, recognized the freedom of its new colony to freely practice

117. Earl Gregg Swem, 15 WiLliam AND MARY Q. 39, 39 (Jan. 1, 1907), https://play.google. com/books/reader?id=ACcjAQAAIAAJ\&hl=en\&pg=GBS.RA1-PA39 [https://perma.cc/48QFRNTF].

118. Id.

119. Thomas Cooper \& Davide James McCord, The Statues at Large of South CARolina, Vol. 2, 1682-1716 271 (1837), https://archive.org/details/statutesatlarge04mccogoog/ page/n300 [https://perma.cc/33EK-47WW].

120. Id.

121. In re Quinlan, 70 N.J. 10, 39 (1976).

122. Cruzan v. Dir., Mo. Dep't of Health, 497 U.S. 261, 279 (1990).

123. Washington v. Glucksberg, 521 U.S. 702, 720 (1997).

124. Death With Dignity, supra note 12.

125. Baxter v. State, 2009 MT 449, P49-P50 (MT 2009).

126. Death With Dignity, supra note 12.

127. Rosalie Jukier \& Jose Woehrling, Religion and the Secular State in Canada 155, 159 Javier Martinez-Torron, W. Cole Durham, Jr., (General Reporters), Donlu D. Thayer, ed. (June 18, 2015), https://papers.ssrn.com/sol3/papers.cfm?abstract_id=2620424 [https://perma.cc/B8YDQLZM]. 
Catholicism. ${ }^{128}$ Britain passed the Quebec Act, 1774, which abolished a required oath of allegiance to the Pope to run for public office. ${ }^{129}$ This legislation marked the starting point of a separated church and state and, more specifically, a secularly insulated judiciary. ${ }^{130}$ For instance, when Canada's Constitution was enacted, it did not reference a connection between state and religion, "and its preamble made no reference to God or to a Supreme Being. ${ }^{131}$

As in the United States, Canada incorporated English common law, including the prohibition of suicide. ${ }^{132}$ The Canadian prohibition of suicide directly stems from Blackstone's commentaries, which, as mentioned earlier, defines suicides as when one "deliberately puts an end to his own existence, or commits any unlawful malicious act, the consequence of which in his own death." ${ }^{.133}$ Early Canadian common law and feudal law prohibited any means by which an individual ended his or her own life because life was viewed as a divine gift that imputed a communal responsibility to live, and such responsibility was incompatible with individual self-determination altogether. ${ }^{134}$ These cultural communal relations both reflect the early restriction in the freedom to end one's life: "No person is entitled to consent to have death inflicted upon him, and such consent does not affect the criminal responsibility of any person by whom death may be inflicted upon the person by whom consent is given." 135

When Canada first introduced its Criminal Code in 1892, suicide was removed as a crime, but it was still likened to murder and punishable under the common law. ${ }^{136}$ Similarly, attempted suicide and aiding and abetting suicide were punishable. Anyone who attempted suicide was sentenced to prison for two years, whereas anyone who "counsel[ed]" or "procure[d]" any person to commit suicide was sentenced to life in prison. ${ }^{137}$ In the 1970 s, Canada recognized the right for the mentally competent to refuse medical intervention, and in 1972, the federal government decriminalized attempted suicide. ${ }^{138}$ Later, in Rodriguez v. British

128. Id.

129. Id.

130. Id.

131. Id.

132. Janet Miron, Suicide, Coroner's Inquests, and the Parameters of Compassion in Ontario, 1830-1900, 47 Soc. Hist. 578, 583 (2014).

133. Id.

134. Bernard M. Dickens, The Right to Natural Death, 26 McGILL L.J. 847, 847 (1981).

135. See id. (noting the connection between early communal relations with restrictions on free will and the statutory restriction to consent to suicide).

136. Miron, supra note 132.

137. S.E. Dawson, The Criminal Code, 1892, 55-56 Victoria, Chap. 29, 95 (1899), https://archive.org/details/criminalcodevic00canagoog/page/n103 [https://perma.cc/LV94-95WC].

138. See generally, Timeline: Assisted Suicide in Canada, Canadian Broadcasting CORPORATION (Feb. 6, 2015), https://www.cbc.ca/news/health/timeline-assisted-suicide-in-canada1.2946485 [https://perma.cc/4A9A-CRS5]. This outlines the history of assisted suicide in Canadian which, after the ban on assisted suicide was upheld, legislative and judicial attempts to overturn assisted suicide grew to be more prevalent. 

THE 49TH PARALLEL

Columbia, a 5-4 decision in 1993, the Supreme Court of Canada, dismissed a challenge to the constitutionality of a physician-assisted suicide. ${ }^{139}$ Soon thereafter, in 2016, the Canadian Supreme Court struck down the assisted-suicide ban, concluding the ban was unconstitutional, in Carter v. Canada. ${ }^{140}$ Following the decision on June 17, 2016, Canadian Parliament enacted an exemption for homicide and aiding suicide when medical practitioners and nurse practitioners provide medical assistance in dying. ${ }^{141}$

\section{CURRENT END-OF-LIFE POLICY IN THE UNITED STATES AND CANADA}

This part first outlines both constitutional tests: U.S. substantive due process under the Fourteenth Amendment and Canada's sections 7 and 1 under the Canadian Charter of Rights and Freedoms ("Charter"). This part then tracks the right to withdraw medical treatment based on the common law and informed consent. Finally, this part distinguishes between the right to refuse medical treatment and physician-assisted suicide under the Fourteenth Amendment of the U.S. Constitution and sections 7 and 1 of the Canadian Charter of Rights and Freedoms ("Charter").

\section{A. Constitutional Comparisons}

\section{United States}

The Due Process Clause of the Fourteenth Amendment states, "No state shall deprive any person of life, liberty, or property without due process of law." ${ }^{142}$ The Due Process Clause protects certain fundamental rights and liberty interests not explicitly mentioned in the Constitution and protects them from certain government actions that may impede the exercise of those rights. ${ }^{143}$ Once a fundamental right or a liberty interest (collectively hereinafter known as "right") is recognized, the Substantive Due Process Clause grants heightened protection against government interference. ${ }^{144}$ Substantive-due-process analysis provides a two-part test: First, the Due Process Clause protects rights that are, objectively,

139. Id.

140. Carter v. Canada (Att'y General), [2015] 1 S.C.R. 331, at para. 147 (Can.), https://scccsc.lexum.com/scc-csc/scc-csc/en/item/14637/index.do [https://perma.cc/QFJ7-SKQL].

141. An Act to Amend the Criminal Code and to Make Related Amendments to Other Acts (Medical Assistance in Dying), S.C. 2016, c 3 (Can.), https://laws-lois.justice.gc.ca/ eng/AnnualStatutes/2016_3/FullText.html [https://perma.cc/EU7R-TJ3K].

142. U.S. Const. amend. XIV, $\S 1$.

143. Washington v. Glucksberg, 521 U.S. 702, 719-20 (internal quotations omitted). Fundamental rights are rights explicitly protected by the Bill of Rights. $I d$. at 720 . Liberty interests are "specific freedoms protected by the Due Process Clause," which include, "the rights to marry, to have children, to direct the education and upbringing of one's children, to marital privacy, to use contraception, to bodily integrity, and to abortion." Id. (internal citations omitted).

144. Id. at 720 . 
"[d]eeply rooted in this Nation's history and tradition" 145 or "[s]o rooted in the traditions and conscience of our people as to be ranked as fundamental," ${ }^{146}$ and "[i]mplicit in the concept of ordered liberty," such that "[n]either liberty nor justice would exist if they were sacrificed." 147 Second, if a right is deeply rooted in the U.S. history and tradition, a careful description of the asserted right must be provided. ${ }^{148}$

Although not explicit in the Constitution, substantive due process was "discovered" in the penumbras of the Bill of Rights, which establishes a zone of privacy that protects rights from government infringement. ${ }^{149}$ If a right is established within the zone of privacy, " $[t]$ he inquiry is whether a right involved is of such a character that it cannot be denied without violating those fundamental principles of liberty and justice which lie at the base of all our civil and political institutions." ${ }^{150}$ The Fourteenth Amendment provides two tests in examining a government's infringement on an individual's rights: strict scrutiny and rational basis review. ${ }^{151}$ If a right is found within the zone of privacy, strict scrutiny forbids the government from infringing on that right, unless the infringement is narrowly tailored to a compelling state interest. ${ }^{152}$ If that right is not found within the zone of privacy, rational basis review permits the government to "abridge" or "abrogate" that right so long as the law is "rationally related to a legitimate state interest." 153

The Supreme Court has found laws to be unconstitutional that are not narrowly tailored to serve a compelling state interest. For instance, Connecticut fined a married couple for using contraceptives. ${ }^{154}$ In doing so, Connecticut argued that the purpose for banning contraceptives (the infringement) was to prevent extra-marital affairs (the state interest). ${ }^{155}$ Although the State argued this

145. Id. at 721 (internal quotations omitted).

146. Id.

147. Id.

148. Id.

149. Griswold v. Connecticut, 381 U.S. 479, 484 (1965). "Various guarantees create zones of privacy. The right of association contained in the penumbra of the First Amendment is one, as we have seen. The Third Amendment in its prohibition against the quartering of soldiers 'in any house' in time of peace without the consent of the owner is another facet of that privacy. The Fourth Amendment explicitly affirms the 'right of the people to be secure in their persons, houses, papers, and effects, against unreasonable searches and seizures.' The Fifth Amendment in its SelfIncrimination Clause enables the citizen to create a zone of privacy which government may not force him to surrender to his detriment. The Ninth Amendment provides: 'The enumeration in the Constitution, of certain rights, shall not be construed to deny or disparage others retained by the people." Id.

150. Id. at 493 (Goldberg Concurring).

151. Glucksberg, 521 U.S. at 766-67 (Souter concurring).

152. Id. at 721 .

153. Lawrence v. Texas, 539 U.S. 558, 598 (2003).

154. Griswold, 381 U.S. at 480.

155. Id. at 498 (Goldberg concurring). 
ban was rationally related to a legitimate government interest of marriage fidelity, the Court rejected this argument using strict scrutiny. The Court reasoned that (1) contraceptives are widely available for other purposes, such as the spread of disease and preventing pregnancy, and (2) Connecticut can pass a more particularized law to protect marital fidelity instead of its broad sweeping ban on contraceptives, such as controls on manufacturing contraceptives. ${ }^{156}$

\section{Canada}

\section{a. Section 7}

Section 7 of the Charter states, "[E]veryone has the right to life, liberty, and security of the person and the right not to be deprived thereof except in accordance with the principles of fundamental justice."157 The first prong contains two elements: (1) the right to life and (2) the right to liberty and security of the person. ${ }^{158}$ First, the right to life involves the preservation of life and is only invoked when government action or laws threaten death. ${ }^{159}$ Although the sanctity of life is included in the right to life, the sanctity of life does not include preserving an individual's life at all costs. ${ }^{160}$

Second, the right to liberty and security of the person are considered together because they are both justified by personal autonomy. ${ }^{161}$ With personal autonomy, section 7 of the Charter protects everyone's right to make decisions concerning his or her body. ${ }^{162}$ Security of the person also protects dignity and privacy of individuals, which supports personal decisions of the body and protects against state interference. ${ }^{163}$ This aligns with the purpose of section 7 , which ensures "human dignity and individual control, so long as it harms no one else."164

The second prong of section 7 looks at the principles of fundamental justice. Three principles of fundamental justice are considered when determining whether the deprivation of a right does not accord with life, liberty, and security of the person. ${ }^{165}$ The deprived right cannot be arbitrary, overbroad, or have consequences that are grossly disproportionate to their objective. ${ }^{166}$ First, legislation is "arbitrary if it bears no relation to, or is inconsistent with, the

156. Id.

157. Canadian Charter of Rights and Freedoms, Part I of the Constitution Act, 1982, being Schedule B to the Canada Act, 1982, c 11, § 7 (U.K.)

158. See Carter v. Canada (Att'y General), [2015] 1 S.C.R. 331, at para. 57-69 (Can.).

159. Id. at para. 61.

160. Id. at para. 63 .

161. Id.

162. Rodriguez v. British Columbia (Att'y General), [1993] 3 S.C.R. 519, 618 (Can.).

163. Id.

164. $I d$.

165. Carter, [2015] 1 S.C.R. at para. 72

166. Id. 
objective that lies behind the legislation." 167 Second, a law is overbroad if it "takes away rights in a way that generally supports the object[ive] of the law," but the law "den[ies] the right to some individuals in a way that bears no relation to the objective." 168 For example, a law is overbroad if the law's sanctioned conduct does not relate to its purpose but "to make enforcement more practical." ${ }^{69}$ Third, a law is grossly disproportionate if the impact of the law is completely out of sync with the law's purpose. ${ }^{170}$ This is determined by comparing the facial purpose of the law to the law's negative effects on the challengers of the law. ${ }^{171}$ The scope of section 7 looks to how the legislation in question affects the challengers individually. ${ }^{172}$

Finally, reviewing both the common law and the legislative history of the offence and the rationale behind the practice itself (e.g., criminalization of assisted suicide) are helpful to discern the principles of fundamental justice governing a particular case. ${ }^{173}$ This review requires a court to ask whether the state's restriction on an individual's bodily integrity violates the principles of fundamental justice. ${ }^{174}$

\section{b. Section 1}

If a court finds that legislation violates section 7 , the legislation may still be upheld under section 1. Section 1 of the Charter provides, "The Canadian Charter of Rights and Freedoms guarantees the rights and freedoms set out in it subject only to such reasonable limits prescribed by law as can be demonstrably justified in a free and democratic society." 175 To justify infringing an individual's section 7 rights under section 1 of the Charter, Canada must show that the law has a pressing and substantial objective and that the means chosen are proportional to that objective. ${ }^{176}$ A law is proportionate if "(1) the means adopted are rationally connected to that objective; (2) it is minimally impairing of the right in question; and (3) there is proportionality between the deleterious and salutary effects of the law." ${ }^{177}$ However, in some instances, the state may show that the public good justifies depriving an individual of life, liberty or security of the person under section 1 of the Charter whereas section 7 looks at the individually deprived right

167. Rodriguez, [1993] 3 S.C.R. at 618.

168. Carter, [2015] 1 S.C.R. at para. 85.

169. Id.

170. Id. at para. 89 .

171. Id.

172. Id.

173. Rodriguez v. British Columbia (Att'y General), [1993] 3 S.C.R. 519, 618 (Can.).

174. Id. at 619 .

175. Canadian Charter of Rights and Freedoms, Part I of the Constitution Act, 1982, being Schedule B to the Canada Act, 1982, c. 11, § 1 (U.K.).

176. Carter, [2015] 1 S.C.R. at para. 94.

177. Id. at para. 85 . 
of the challengers. ${ }^{178}$

\section{Comparison of Provisions}

Section 7 and the Fourteenth Amendment are similar in defining what rights are constitutionally protected. First, the language of both are quite similar. The Due Process Clause states, "No state shall deprive any person of life, liberty, or property without due process of law." right to life, liberty and security of the person and the right not to be deprived thereof except in accordance with the principles of fundamental justice." ${ }^{\prime 10}$ The Due Process Clause's and section 7's language is on point concerning which rights are protected such that the United States protects "life, liberty, or property" and Canada protects "life, liberty and security." Although "property" and "security" protections are different, both U.S. and Canadian courts have interpreted their respective protections to protect the privacy of individuals and the right to make personal decisions concerning one's own body. ${ }^{181}$

When considering whether a particular right falls under life, liberty, or property of the Due Process Clause, U.S. courts analyze history to determine the historical extent of the right's protection. ${ }^{182}$ As in the United States, Canadian courts similarly frame their rights by looking at legislative history, so they can understand the historical status of the law and the reasons for its enactment. ${ }^{183}$ The scope of history may differ depending on the right examined; however, for the purposes of the right to refuse medical treatment, the United States and Canada share an identical historical scope and analysis. ${ }^{184}$

Both rational basis review under "due process" of the Fourteenth Amendment

178. Id. at para 95 .

179. U.S. Const. amend. XIV § 1.

180. Canadian Charter of Rights and Freedoms, Part I of the Constitution Act, 1982, being Schedule B to the Canada Act, 1982, c. 11, § 1 (U.K.).

181. See generally Jean McBean, The Implications of Entrenching Property Rights in Section 7 of the Charter of Rights, 26 ALBERTA L. REV. 548, 551-61 (1988) (comparing U.S. property protection under the Fourteenth Amendment to the Canadian security of person under section 7). United States Courts have protected various personal body choices: Planned Parenthood v. Casey, 505 U.S. 833, 879 (1992) (protecting a woman's right to terminate her pregnancy before viability of the fetus outside of the womb); Lawrence v. Texas, 539 U.S. 558 (protecting homosexual couples' right to sodomy). "The Casey decision again confirmed that our laws and tradition afford constitutional protection to person decisions relating to marriage, procreation, contraception, family relationships, child rearing, and education." Id. at 574. Canadian Courts have found similar rights to bodily integrity: R v. Morgentaler, 62 CR 3d 1, 31 (1988) (reasoning that a requirement to seek approval for an abortion threatened a woman's physical and psychological security by denying her a potentially necessary medical procedure).

182. Washington v. Glucksberg, 521 U.S. 702, 721 (1997).

183. Rodriguez v. British Columbia (Att'y General), [1993] 3 S.C.R. 519, 618 (Can.).

184. Infra Part II.B.1. 
and Canada's section 7 "fundamental justice" test are similar to the extent that they minimally restrict the scope of government infringement on a constitutional right. ${ }^{185}$ Canada requires that for a law to comport with fundamental justice, the law cannot be arbitrary such that it bears no relation to the objective behind the legislation; cannot be overbroad to take away rights that generally support the objective of the law; and cannot be grossly disproportionate if the impact of law is completely out of sync with the law's purpose. ${ }^{186}$ These principles are similarly reflected in the U.S. test for rational basis review: permitting the government to abrogate or abridge a liberty interest so long as the law is rationally related to a legitimate state interest. ${ }^{187}$

Consider Griswold under rational basis review (but note that the U.S. Supreme Court rejected the contraceptive ban under strict scrutiny). In Griswold, contraceptives were banned (rationally related infringement) to protect marital fidelity (legitimate state interest). ${ }^{188}$ First, as in section 7's overbroad requirement, the contraceptive ban was overbroad because it encompassed both the purpose to marital infidelity and other purposes, such as preventing disease and conception. ${ }^{189}$ Second, as in the arbitrary requirement of section 7, the contraceptive ban was not entirely arbitrary because the U.S. Supreme Court required that the law be more narrowly tailored to protect against marital infidelity, implying that it has some relation to its objective of protecting against marital fidelity. ${ }^{190}$ Third, as in the grossly disproportionate requirement of section 7, the U.S. Supreme Court does not discuss whether a contraceptive ban reduces extra-marital relations, but if it did, the law would not be grossly disproportionate under section $7 .{ }^{191}$

Another similarity is strict scrutiny under the Due Process Clause and section 1. Section 1 requires (1) the means adopted are rationally connected to that objective; (2) the means are minimally impairing of the right in question; and (3) there is proportionality between the deleterious and salutary effects of the law. ${ }^{192}$ Strict scrutiny requires that the government infringement be narrowly tailored to a compelling state interest. ${ }^{193}$ For prong 1 , although section 1 has similar language to the U.S. rational basis test, section 7 has a lower threshold than section 1 when determining whether a state law infringes on a person's life, liberty, and security. Prong 2 is most indicative in its likeness to strict scrutiny because Canadian law must be minimally impairing, just as a U.S. law must be narrowly tailored. Prong 3 weighs the impact on protected rights against the beneficial impact for the

185. But see Gwen C. Mathewson, Security of the Person, Equality and Abortion in Canada, 1989 Univ. Chi. LeGAL F. 251, 257 (1989).

186. Carter v. Canada (Att'y General), [2015] 1 S.C.R. 331, at para. 72 (Can.).

187. Glucksberg, 521 U.S. at 721.

188. Griswold v. Connecticut, 381 U.S. 479, 498 (1965).

189. Id.

190. $I d$.

191. See id.

192. Carter v. Canada (Att'y General), [2015] 1 S.C.R. 331, at para. 94 (Can.).

193. Washington v. Glucksberg, 521 U.S. 702, 721 (1997). 
greater good, ${ }^{194}$ and, similarly, U.S. courts weigh the state interest and greater good (e.g., protecting marital fidelity) against the impacted right of individuals (e.g., the privacy of married couples to use contraceptives). ${ }^{195}$

\section{B. Right to Refuse Medical Treatment}

\section{The Common Law}

The right to refuse medical treatment means, "The right of a terminally ill person to refuse life-sustaining treatment." 196 The right to refuse medical treatment contemplates refusing treatment at two junctures - (1) refusing medical treatment before it is administered and (2) refusing medical treatment after the patient first consented to the administration of medical treatment and then refusing its continuance. Both actions stem from the patient's choice: to be free from medical treatment.

\section{a. United States}

In Cruzan v. Director, Mo. Dept. of Health, the Supreme Court concluded the Due Process Clause of the Fourteenth Amendment protects the right to refuse lifesaving medical treatment. ${ }^{197}$ The Court first identified the right to refuse medical treatment based on the doctrine of informed consent. ${ }^{198}$ Informed consent presumes that a patient is both competent and "has the information necessary to evaluate the risks and benefits of all the available options." ${ }^{\prime 99}$ The Court stated that U.S. common law sanctioned the unconsented touching of another as battery. ${ }^{200}$ Personal autonomy is most important when considering that people generally have a right in choosing what will be done with their own body, and physicians who perform unconsented medical treatment are liable for damages. ${ }^{201}$ Therefore, an individual may reject medical treatment before it is administered or may also withdraw consent, after consent was given, from medical treatment at any point during treatment.

194. Carter, [2015] 1 S.C.R. at para. 122.

195. Griswold v. Connecticut, 381 U.S. 479, 498 (1965).

196. Right to Refuse Treatment, Black's LAW Dictionary (11th ed. 2019).

197. Cruzan v. Director, Mo. Dept. of Health, 497 U.S. 261, 280 (1990). The Court's specific inquiry is whether an incapacitated individual has the right to withdraw consent where Missouri applied a higher standard of proof for decision makers acting on her behalf.

198. See id. at 269.

199. In re Conroy, 98 N.J. 321, 347 (1985).

200. Cruzan, 497 U.S. at 269.

201. Id. (citing Schloendorff v. Society of New York Hospital, 211 N.Y. 125, 129-30 (1914)). 


\section{b. Canada}

Canada parallels the U.S. right to refuse medical treatment in relying on the history of informed consent. The Supreme Court of Canada recognized a right to refuse medical treatment under Canadian common law. ${ }^{202}$ This right was recognized by the Supreme Court of Canada in Ciarlariello v. Schacter. ${ }^{203}$ The issue before the Court was whether a reasonable person in the patient's position would want to know the risks involved with discontinuing medical treatment. ${ }^{204}$ The court stated that focus should be directed toward what the patient would like to know about continuing treatment once the patient withdraws consent. ${ }^{205}$ "Objectively, a patient would want to know whether there had been any significant change in the risks involved or in the need for the continuation of [treatment] which had become apparent during the course of the [medical] procedure." ${ }^{206}$

The requirement that disclosure be made to the patient is based on the concept of individual autonomy. ${ }^{207}$ An individual can choose what to do with his or her body, which includes the right of bodily integrity to determine the extent to which medical procedures are accepted..$^{208}$ Therefore, if an individual can consent to treatment, the converse is true. ${ }^{209}$ During the medical procedure, a patient withdraws the consent to that procedure, and the physician has a duty to stop, which recognizes an individual's basic right to make decisions concerning his or her body. ${ }^{210}$ As mentioned before, when material changes arise that could alter a patient's decision about continuing treatment, the physician bears the burden to ensure that the patient understands the explanation and to follow the patient's instructions related to refusing treatment. ${ }^{211}$ Individual autonomy is fundamental to Canadian common law and is the foundation for requiring physicians to inform patients of related risks. ${ }^{212}$

The right to refuse medical treatment also extends to cases when the refusal results in death. In Malette $v$. Shulman, the doctrine of informed consent encompasses the right to refuse medical treatment even if the decision results in death or the medical profession disapproves. ${ }^{213}$ For the freedom of choice and

202. Rodriguez v. British Columbia (Att'y General), [1993] 3 S.C.R. 519, 554 (Can.).

203. Ciarlariello v. Schacter, [1993] 2 S.C.R. 119, 135.

204. Id. at 133 .

205. Id. at 121.

206. Id.

207. Id. at 135 .

208. Id.

209. Ciarlariello v. Schacter, [1993] 2 S.C.R. 119, 135.

210. See id. at 142. The procedure must be stopped unless medical evidence suggests that terminating the process would be either life threatening or pose immediate and serious problems to the patient's health. Id.

211. Id. at 122 .

212. Id. at 135 .

213. See generally Malette v. Shulman (1990), 72 O.R. (2d) 417 (C.A.). 

THE 49TH PARALLEL

autonomy to be meaningful, people must have the right to make choices based on their values regardless of others' perception or opinions. ${ }^{214}$

\section{Constitutional Protections}

Both the United States and Canada incorporated the common law and informed consent into their respective constitutional provisions. ${ }^{215}$ The United States recognized the right to refuse medical treatment under the Due Process Clause of the Fourteenth Amendment, ${ }^{216}$ the Supreme Court of Canada, in Rodriguez v. British Columbia, referred to the right to refuse medical treatment in its first right to physician-assisted suicide case. ${ }^{217}$ The Supreme Court of Canada referred to the right to refuse medical treatment when analyzing the history and status of laws in right to die cases, but it never directly incorporated the right to refuse medical treatment into section $7 .{ }^{218}$ After establishing the right to autonomy for the right to refuse medical treatment under both constitutional provisions, the standard of autonomy is tracked through the United States and Canada. This part sets out the constitutional provisions and their tests that were used to determine the constitutionally protected right to refuse medical treatment. These tests also apply to the later physician-assisted suicide section, outlining the logic for both countries.

\section{a. U.S. Substantive Due Process}

In re Quinlan was one of the first right-to-refuse-medical-treatment cases in the United States. ${ }^{219}$ The majority, in Cruzan v. Dir., Missouri Department of Health, concluded that this right was protected under the Due Process Clause. ${ }^{220}$ Soon thereafter, the Glucksberg Court reaffirmed the right to refuse medical treatment. ${ }^{221}$

\section{i. History and Traditions}

As discussed earlier, the Cruzan Court conducted a historical review of the laws underlying the right to refuse lifesaving medical treatment in the Due Process Clause. ${ }^{222}$ This historical review comports with the first prong of the

214. Id.

215. Cruzan v. Director, Mo. Dept. of Health, 497 U.S. 261, 269-70 (1990); Carter v. Canada (Att'y General), [2015] 1 S.C.R. 331, at para. 67 (Can.).

216. Cruzan, 497 U.S. at 279.

217. Rodriguez v. British Columbia (Att'y General), [1993] 3 S.C.R. 519, 598 (Can.).

218. Id. at 591.

219. See generally In re Quinlan, 70 N.J. 10 (1976).

220. 497 U.S. 261, 279 (1990).

221. Washington v. Glucksberg, 521 U.S. 702, 724 (1997).

222. Cruzan v. Director, Mo. Dept. of Health, 497 U.S. 261, 269 (1990); see supra, Part 2.A.1. 
substantive due process analysis, determining whether a right is grounded in the zone of privacy. ${ }^{223}$ After determining that the right to refuse medical treatment falls within the zone of privacy, U.S. courts must weigh a right to refusing medical treatment against pertinent state interests that infringe on that right. ${ }^{224}$

\section{ii. State Interest Versus Individual Autonomy}

State courts have found a substantive right protected under the Fourteenth Amendment, and these courts are referenced to inform weighing liberty and state interests. In re Quinlan (decided before Cruzan) determined that the broad right to implied privacy in the Constitution affords protections for an individual to refuse medical treatment. ${ }^{225}$ The court weighed the liberty interest in refusing treatment against two major state interests: the preservation and sanctity of human life and the physician's right to administer medical treatment according to the physician's best judgment. ${ }^{226}$ The New Jersey Supreme Court weighed the competing interests on a sliding scale - the state's interest weakens and the individual's right to privacy grows as medical treatment intruding on the patient's body increases and the likelihood of survival decreases. ${ }^{227}$ When an individual is fully competent, the individual's autonomy outweighs most bodily invasions by the state, even when death is likely. ${ }^{228}$

A subsequent New Jersey Supreme Court case both reaffirmed and included additional countervailing state interests: preserving life, preventing suicide, safeguarding the integrity of the medical profession, and protecting innocent third parties. ${ }^{229}$ Although the patient in question was unconscious, the New Jersey Supreme Court concluded that if she were conscious, her free will to refuse treatment would outweigh the state's interest in preserving the sanctity of human life. ${ }^{230}$ However, preserving life was the most significant of the factors considered. ${ }^{231}$

Similarly, the Supreme Court of Massachusetts relied on the right to privacy in Griswold v. Connecticut, which supported the right to refuse medical treatment already administered based on human dignity and self-determination even if it

223. Griswold v. Connecticut, 381 U.S. 479, 484 (1965).

224. Cruzan, 497 U.S. at 280. The Court's specific inquiry is whether an incapacitated individual has the right to withdraw consent where Missouri applied a higher standard of proof for decision makers acting on her behalf.

225. In re Quinlan, 70 N.J. 10, 39 (1976).

226. Id. at 40 .

227. Id. at 41 .

228. Id.

229. In re Conroy, 98 N.J. 321, 348-49 (1985).

230. In re Quinlan, 70 N.J. at 41 . The New Jersey Supreme Court weighed state and liberty interests on a sliding scale: "We think that the State's interest contra weakens and the individual's right to privacy grows as the degree of bodily invasion increases and the prognosis dims." Id.

231. In re Conroy, 98 N.J. at 349. 

THE 49TH PARALLEL

would lead to death. ${ }^{232}$ The court affirmed this right based on similar considerations. ${ }^{233}$ In most circumstances, when considering a person's right to refuse medical treatment against the state's interests (the preservation of life; the protection of the interests of innocent third parties; the preservation of suicide; and maintaining the ethical integrity of the medical profession), the individual's rights generally prevail. ${ }^{234}$

In California, a state appellate court also found that a right to refuse medical treatment is basic and fundamental as part of the right of privacy in Griswold v. Connecticut. ${ }^{235}$ Just like the Cruzan Court, the Bouvia court, in citing California state court cases, reasoned that a physician's unconsented treatment was battery. ${ }^{236}$ If a physician cannot treat patients without their consent, patients must then have a right to refuse medical treatment. ${ }^{237}$ The Bouvia court, recognizing a patient's decision-making process, noted that the patients' interests and desires are extremely important. ${ }^{238}$ This line of reasoning contradicts the trial court, which considered the patient's motivations for refusing medical treatment. ${ }^{239}$ The patient has a right to refuse medical treatment, so the motivations or reasons for accepting or refusing medical treatment do not matter. ${ }^{240}$

Reasons for refusing medical treatment are reserved for the patient and another's opinions of those motivations are not important. Whose right is it to decide whether a patient wants a quicker natural death but the patient's? ${ }^{241}$ The Bouvia Court highlighted that a natural death meant dying without assistance (e.g., feeding tube) as opposed to the direct cause of the death (e.g., starvation or the disease). ${ }^{242}$

\section{Physician-Assisted Suicide}

This part follows the U.S. substantive due process analysis, broken down into two sub-parts: Historical Analysis and Weighing State Interests. The Historical Analysis sub-part is divided into three sections. The first two sections establish how the United States and Canada each concluded whether physician-assisted suicide was a constitutionally protected right. The third section reasons that three approaches the U.S. Supreme Court takes in its physician-assisted suicide

232. Superintendent of Belchertown State School v. Saikewicz, 370 N.E.2d 417, 424 (Mass. 1977).

233. Id.

234. See id. at 425 .

235. Bouvia v. Super. Ct., 179 Cal. App. 3d 1127, 1137 (1986).

236. Id.

237. Id. at 1138 .

238. Id.

239. Id. at 1145 .

240. Id.

241. Id.

242. Id. 
analysis are illogical, will be informed with the Canadian analysis, and supported by religious arguments. The Weighing State Interests sub-part is divided into four sections based on the four major U.S. state interests that U.S. courts weigh against the right to physician-assisted suicide-preserving life and preventing suicide, integrity of the medical profession, and protecting innocent third-parties. The merits of each state interest are considered in-turn and weighed against an individual's right to physician-assisted suicide.

\section{Historical Analysis}

Euthanasia and physician-assisted suicide are generally related concepts in that they involve the agreement between a physician and a patient to consensually end the patient's life. The difference between euthanasia and physician-assisted suicide is a result of how the death is caused. Euthanasia occurs "[w] hen a person (generally a physician) administers a medication, such as a sedative and neuromuscular relaxant, to intentionally end a patient's life with the mentally competent patient's explicit request." 243 Physician-assisted suicide is "[w]hen the physician provides medication or a prescription to a patient at his or her explicit request with the understanding that the patient intends to use the medications to end his or her life."244

\section{a. United States}

Although some states legalized physician-assisted suicide by statute, the U.S. Supreme Court unanimously rejected a constitutionally protected right to physician-assisted suicide, unlike the right to refuse medical treatment. ${ }^{245}$ In Washington v. Glucksberg, three doctors from Washington challenged Washington's physician-assisted suicide ban under the Due Process Clause of the Fourteenth Amendment. ${ }^{246}$ The law stated, "A person is guilty of promoting a suicide attempt when he knowingly causes or aids another person to attempt suicide." ${ }^{247}$ The Court first began its substantive due process analysis with the U.S. "history, legal traditions, and practices." ${ }^{248}$ In 1997, when Glucksberg was published, the Court noted that most Western countries and the United States prohibited physician-assisted suicide. ${ }^{249}$ Then, reviewing U.S. history, it determined that suicide was banned both under English common law (later

243. Ezekiel J. Emanuel et al., Attitudes and Practices of Euthanasia and Physician-Assisted Suicide in the United States, Canada, and Europe, 316 JAMA 80, 81 (July 5, 2016), https://jamanetwork.com/journals/jama/article-abstract/2532018 [https://perma.cc/3BUW-FMTE] (emphasis omitted).

244. Id.

245. Washington v. Glucksberg, 521 U.S. 702, 735 (1997).

246. $I d$. at 707 .

247. Id. (citing WASH. ReV. CODE § 9A.36.060(1) (1994)).

248. Id. at 710 .

249. Id. 

THE 49TH PARALLEL

adopted by the colonies) and the founding U.S. colonies prohibited suicide. ${ }^{250}$ Finally, an investigation into the consensus of laws at the time of the Fourteenth Amendment determined that aiding or abetting suicide was prohibited, which did not support the right to physician-assisted suicide. ${ }^{251}$

After its historical analysis, the Court concluded that the Due Process Clause liberty protection does not include the right to choose the time and manner of one's death and that a historically banned practice requires a strong case to overturn it. ${ }^{252}$ The challenging physicians argued that substantive due process encapsulated a general tradition of "self-sovereignty" and liberty included "basic and intimate exercises of personal autonomy," according to Cruzan. ${ }^{253}$ Because Cruzan afforded a right to refuse medical treatment under the U.S. common law, the physicians continued that the characterization under the U.S. common law afforded a right to hasten death through lethal medication. ${ }^{254}$ The Court rejected this argument stating that Cruzan "was not simply deduced from abstract concepts of personal autonomy," but the right to refuse medical treatment has had consistent legal protections, as opposed to physician-assisted suicide. ${ }^{255}$ However, the Court acknowledged that physician-suicide suicide and refusing medical treatment are both personal and profound decisions. ${ }^{256}$

The Vacco Court distinguished the right to refuse medical treatment from physician-assisted suicide based on cause and intent. ${ }^{257}$ First, the causal distinction refers to when a patient refuses life-sustaining medical treatment; the patient dies from the disease. ${ }^{258}$ For physician-assisted suicide, a person who either ingests physician-prescribed medication dies from the medication. ${ }^{259}$ This causal distinction has also been recognized in state courts. ${ }^{260}$ Second, when a patient refuses life-sustaining medical treatment, the physician complies with the patient's request, and the physician intends to respect the patient's autonomy in freely refusing medical treatment due to the patient's subjective beliefs. ${ }^{261}$ When a physician prescribes or provides lethal medication, both the patient and the physician unequivocally intend the patient's death, whereas the patient refusing treatment may not intend to die but, instead, to be free of unwanted treatment. ${ }^{262}$

250. Id. at 711-14.

251. Id. at $714-16$.

252. Id. at 723 .

253. Id. at $723-24$.

254. Id. at 725 .

255. Id.

256. $I d$.

257. Vacco v. Quill, 117 S. Ct. 2293, 2298 (1997).

258. Id.

259. Id.

260. In re Conroy, 98 N.J. 321, 352 (1985); Bouvia v. Super. Ct., 179 Cal. App. 3d 1127, 1145 (1986).

261. Vacco, 117 S. Ct. at 2298.

262. Id. 
Courts have rejected action-inaction distinctions between refusing medical treatment and physician-assisted suicide. ${ }^{263}$ Refusing medical treatment before or after treatment is administered is an omitted act even though a physician needs to act to remove administered medical treatment. However, if a patient wishes to die affirmatively (by one's own act), then choosing death by lethal medication or pain relief (anything other than natural causes) is impermissible because the patient dies as a result of his or her affirmative actions (and in tandem with the physician) rather than dying of natural causes (the effects absent medical treatment). Although refusing medical treatment and physician-assisted suicide are logically different, they both result in the patient's death. Justice Scalia recognized the facial impossibility in distinguishing death between action and inaction: "It would not make much sense to say that one may not kill oneself by walking into the sea, but may sit on the beach until submerged by the incoming tide . .."264 Applied to the distinction at hand, refusing a feeding tube and ingesting lethal medication are both actions that both cause the patient's death. Based on the foregoing, the clearer distinction between refusing treatment and physician-assisted suicide is based on cause and intent rather than action and inaction.

In sum, physician-assisted suicide was not afforded the same constitutional protection as the right to refuse medical treatment. First, the status of the U.S. laws historically prohibited suicide and physician-assisted suicide. Second, courts have distinguished refusing treatment and physician-assisted suicide on the bases of cause and intent. Because physician-assisted suicide was not afforded the same historical or logical treatment, Glucksberg did not recognize physician-assisted suicide as a liberty interest found within the zone of privacy of the Due Process Clause under the Fourteenth Amendment. ${ }^{265}$

\section{b. Canada}

In Carter v Canada, the Canadian Supreme Court found that there was a constitutionally protected right to physician-assisted suicide under sections 7 and 1 of the Charter. This sub-part addresses the first provision of section 7: "[E]veryone has the right to life, liberty, and security of the person . .."266 The plaintiff challenged the constitutionality of various provisions in the Criminal Code that prohibited physician-assisted suicide. ${ }^{267}$

The Court turned to section 7 of the Charter to determine if the law banning physician-assisted suicide infringed on (1) the right to life and (2) the right to

263. See Cruzan v. Director, Mo. Dept. of Health, 497 U.S. 261, 296 (1990) (Scalia

concurring) (citing cases that reject the action-inaction distinction).

264. Id.

265. Washington v. Glucksberg, 521 U.S. 702, 735 (1997).

266. Canadian Charter of Rights and Freedoms, Part I of the Constitution Act, 1982, being Schedule B to the Canada Act, 1982, c. 11, 7 (U.K.).

267. Id. 
liberty and security of the person. ${ }^{268}$ For the first prong, the Court concluded that prohibiting physician-assisted suicide "had the effect of forcing some individuals to take their own lives prematurely, for fear that they would be incapable of doing so when their suffering was intolerable." ${ }^{269}$ The Court accepted the trial judge's rejection of the "qualitative" approach to the right to life because such an approach would create a "duty to live," rather than a "right to life," and would call in to question the legality of any consent refusing any medical treatment. ${ }^{270}$ This takes a broader view of the preservation of life to reject the natural death approach to ending a life on the grounds of what legally imposed duty there would be otherwise. ${ }^{271}$

For the second prong, the Court concluded that liberty involves "the right to make fundamental personal choices free from state interference," and security involves "a notion of personal autonomy involving . . . control over one's bodily integrity free from state interference." ${ }^{272}$ With liberty and security considered together, the plaintiff would suffer from pain while being deprived of control over her body. ${ }^{273}$ "This is a decision that is rooted in [patients'] control over their bodily integrity; it represents their deeply personal response to serious pain and suffering. By denying them the opportunity to make that choice, the prohibition impinges on their liberty and security of the person." ${ }^{274}$ Like refusing medical treatment to control bodily decisions, physician-assisted suicide is just a means for a patient to control his or her life. ${ }^{275}$ The Court also reasoned that informed consent to "decide one's own fate" encompasses the right to refuse medical treatment and the right to physician-assisted suicide. ${ }^{276}$

\section{c. Religious Justification Against Physician-Assisted Suicide}

\section{i. Appeal to Tradition}

Both the Cruzan and Glucksberg Courts conducted a review of the history of laws; however, both logically departed from each other. Cruzan followed the U.S. history of informed consent and battery, reasoning that both provided a person with bodily autonomy to refuse or consent to medical treatment. ${ }^{277}$ However, Glucksberg merely reviewed the status of the laws in England, the Thirteen

Colonies, and nineteenth-century United States and concluded that no right to

268. Carter v. Canada (Att'y General), [2015] 1 S.C.R. 331, at para. 57-69 (Can.).

269. Id. at para. 57.

270. Id. at para. 61-63.

271. $I d$.

272. Id. at para. 64 .

273. Id. at para. 65 .

274. Id.

275. Id. at para. 68 .

276. Id. at para. 67.

277. Cruzan v. Director, Mo. Dept. of Health, 497 U.S. 261, 269 (1990). 
physician-assisted suicide existed because the practice was always prohibited. ${ }^{278}$

Having utilized two different historical perspectives, the U.S. Supreme Court decision proves to be logically inconsistent. First, in Cruzan, the U.S Supreme Court looked at the underlying justification for the right to refuse medical care, relying on informed consent and battery, ${ }^{279}$ whereas in Glucksberg, the U.S. Supreme Court relied on the status of laws having historically banned physicianassisted suicide. ${ }^{280}$ In contrast to Glucksberg, the Canadian Supreme Court was consistent with its historical analysis in Carter because it considered the underlying justification for the state of the laws. ${ }^{281}$ The Carter Court recognized a consistent, logical pattern that followed from informed consent and valued bodily autonomy. ${ }^{282}$ Because informed consent supports the decision to make choices regarding what happens to one's body, so too does it support that choice when it involves physician-assisted suicide. If the Glucksberg Court relied on the foundational autonomy of informed consent in Cruzan, and the similar autonomy derived from Carter, this would lead to a more consistent outcome in U.S. court decisions.

Instead of adopting a more consistent approach, similar to Carter, the Glucksberg Court poisons the well, stating that the right to refuse lifesaving hydration and nutrition was "not simply deduced from abstract concepts of autonomy." 283 However, merely categorizing autonomy as "abstract" does not actually address the argument of autonomy itself. The Glucksberg Court, however, relied on the historical status of U.S. legislation in refusing constitutional protection to physician-assisted suicide. ${ }^{284}$ The Supreme Court of Canada cautioned against the use of a strictly historical analysis because the nonrecognition of a constitutional right relies on the continued prohibition of the right in question. ${ }^{285}$ The Glucksberg Court relied on the continued prohibition of physician-assisted suicide to justify its non-recognition under the Constitution. ${ }^{286}$ Natural Law Theorist John Locke's Essay on the Law of Nature paralleled the Supreme Court of Canada's caution for a strict historical analysis:

That suicide has been practiced in and sanctioned by different societies at different times is no proof that the practice is sanctioned by natural law for "if any law of nature would seem to be established among all as sacred in the highest of degree . . . surely this is self-preservation . . . . But in fact, the power of custom and opinion based on traditional ways

278. See generally Washington v. Glucksberg, 521 U.S. 702, 710-19, 728 (1997).

279. Cruzan, 497 U.S. at 269.

280. Glucksberg, 521 U.S. at $710-19,728$.

281. Carter, [2015] 1 S.C.R. at para. 67.

282. Id.

283. Glucksberg, 521 U.S. at 725.

284. Id. at 710-19, 728 .

285. Rodriguez v. British Columbia (Att'y General), [1993] 3 S.C.R. 519, $591-92$ (Can.).

286. Glucksberg, 521 U.S. at 710-19, 728. 
of life is such as to arm men even against their own selves."287

Because the Glucksberg Court relied on the facial status of the laws, it also relied on the reasons for passing those laws. ${ }^{288}$ Historically, the Thirteen Colonies incorporated English common law and its associated religious sentiment. ${ }^{289}$ As a result, the Glucksberg Court adopted these religious pronouncements while failing to recognize physician-assisted suicide in the zone of privacy.

The Glucksberg Court cited the English common law ban on suicide, and it left out the religious justification for the English common law ban. ${ }^{290}$ Sir William Blackstone stated, "The law of England wisely and religiously considers that no man hath a power to destroy life, but by commission from God, the author of it; and, as the suicide is guilty of a double offense, one spiritual, in invading the prerogative of the Almighty." ${ }^{291}$ English common law punished those who committed suicide with forfeiture and a disgraceful burial, which was also implemented in the states, but they were later repealed. ${ }^{292}$ Justice Scalia summarized why the states repealed these punishments - It was to "spare the innocent family and not to legitimize the act. ${ }^{2293}$ Forfeiture and disgraceful burial were punishments explicitly left out in William Penn's Pennsylvania Charter of Privileges, but the justification for banning suicide remained religious. ${ }^{294}$ The Charter espoused,

BECAUSE no People can be truly happy, though under the greatest Enjoyment of Civil Liberties, if abridged of the Freedom of their Consciences, as to their Religious Profession and Worship: And Almighty God being the only Lord of Conscience, Father of Lights and Spirits; and the Author as well as Object of all divine Knowledge, Faith and Worship, who only doth enlighten the Minds, and persuade and convince the Understandings of People . . . 295

The Glucksberg Court's reasoning is an objective view of history based on the mere status of laws, but this surface level view does not consider the justification for those laws. The religious justification for such laws are still present. A test derived from this view would only recognize rights espoused by the Bible and the religious founding of the United States.

287. Marzen et al., supra note 35, at 42 .

288. See generally Glucksberg, 521 U.S. at 712-20.

289. See supra, Part I.A-C; see supra, Part II.A.

290. Glucksberg, 521 U.S. at 711-12.

291. William Blackstone, Commentaries on the Laws of England 189 (University of Chicago Press 1765).

292. Cruzan v. Director, Mo. Dept. of Health, 497 U.S. 261, 294 (1990).

293. Id.

294. Penn, supra note 116.

295. Id. 


\section{ii. Causation: Natural Death}

The Supreme Court has distinguished between physician-assisted suicide and the right to refuse medical treatment based on the patient's cause of death. Carter does not make a causal distinction between the two rights, so it is not directly instructive to the U.S. Supreme Court's distinction on this issue. ${ }^{296}$ However, Vacco v. Quill distinguished the two actions based on causation. The Court stated that the right to refuse medical treatment contemplates that the underlying disease caused the patient's death, and the right to physician-assisted suicide posits that the patient dies from unnatural intervention - the ingested lethal medication. ${ }^{297}$

The aforementioned distinction parallels an action-inaction dichotomy. Justice Scalia illustrated the facial impossibility to distinguish death between action and inaction: "It would not make much sense to say that one may not kill oneself by walking into the sea, but may sit on the beach until submerged by the incoming tide ..." "298 Justice Scalia continued, "Starving oneself to death is no different from putting a gun to one's temple as far as the common-law definition of suicide is concerned. ${ }^{299}$ Regardless of the agent that causes the death or the medium used, the choice of death flows from the patient. Just as the actioninaction dichotomy is a distinction without a difference so too is distinguishing both end-of-life decisions based on the medium that causes the death.

Justice Gorsuch illustrates another distinction between refusing medical treatment and physician-assisted suicide based on causation in the following example:

To illustrate the role human choice plays, consider a doctor who terminates life-sustaining care for purely selfish reasons - because he or she stands to inherit money, has a grudge against the patient, whatever. What is the cause of death in such cases? To be sure, the patient would have died sooner as a result of the "natural" underlying malady but for the intervening life-sustaining medical care. At the same time, the patient would not have died at that moment but for the human choice to kill. ${ }^{300}$

When considering the right to refuse medical treatment both before and after it is administered, the patient chooses what to do with his or her own body. Justice Gorsuch stated that the physician with mal-intent causes the death depending on his or her intent when withdrawing treatment (i.e., without the consent of the patient). ${ }^{301}$ In a criminal context, the physician who withdrew treatment is the cause of the death because the physician violated the patient's

296. See Carter v. Canada (Att'y General), [2015] 1 S.C.R. 331 (Can.).

297. 117 S. Ct. 2293, 2298 (1997).

298. Cruzan v. Director, Mo. Dept. of Health, 497 U.S. 261, 296 (1990) (Scalia concurring).

299. $I d$.

300. Neil M. Gorsuch, The Future of Assisted Suicide and Euthanasia 55 (Robert P. George ed., Princeton University Press 2006).

301. Id. 

THE 49TH PARALLEL

personhood without the patient's consent. ${ }^{302}$ The physician would either be guilty of malpractice (negligence) or criminal murder (some form of criminally defined intent). However, when the patient consents to refusing medical treatment or physician-assisted suicide, the patient dies as a result of the patient's choice. Technically, the distinction Justice Gorsuch makes is based on the physician violating a duty to treat the patient by removing treatment to cause a quicker death. Although the physician may have a nefarious motive to kill the patient and has a disregard for the patient's life, the patient still dies from natural causes of removed treatment regardless of when treatment is removed.

Having reasoned that the natural death distinction between the right to refuse medical treatment and physician-assisted suicide is illogical and untenable, dying a natural death closely parallels the Christian definition of natural death. ${ }^{303} \mathrm{~A}$ death must occur naturally on God's terms, without unnatural assistance or in any way preempted by the individual ${ }^{304}$ because any affirmative act of suicide or physician-assisted suicide would have abrogate God's sovereignty, property interest, and his creation of human life. ${ }^{305}$ Similarly, U.S. courts noted that "natural death" was a result from the underlying disease, starvation, dehydration, or some other natural side-effect as a result of absent medical treatment. ${ }^{306}$

Justice Stevens famously stated, "In my view, however, it is an effort to define life, rather than to protect it, that is the heart of Missouri's policy." 307 Justice Stevens also noted the difficulty in establishing constitutional significance of death and that death is more related to faith, reasoning that the freedom to make choices about death should be left to personal choice. ${ }^{308}$ Justice Stevens continued, "Many philosophies and religions have, for example, long venerated the idea that there is a 'life after death,' and that the human soul endures even after the human body has perished. Surely Missouri would not wish to define its interest in life in a way antithetical to this tradition." ${ }^{309}$ According to Justice Stevens, Missouri was both trying to define life and make an appeal that individual decisions of death should be decided based on an individual's religion. However, his statements noted that Missouri attempted to uphold a religious view of life and attempted to define simultaneously.

In the same vein as Missouri, the Kentucky Supreme Court defined its interest in life. The Kentucky Supreme Court explicitly used religious justification in defining ethical standards for end-of-life treatment - the court cited Pope Pius XII of the Catholic Church and his acceptance of moralities of

302. $I d$.

303. Genesis 3:19.

304. Slick, supra note 32.

305. Previn, supra note 14, at 595; Genesis 1:26-27.

306. Vacco v. Quill, 117 S. Ct. 2293, 2308 (1997) (Stevens concurring); In re Conroy, 98 N.J. 321, 335 (1985); Rasmussen by Mitchell v. Fleming, 154 Ariz. 207, 218 (1987).

307. Cruzan v. Director, Mo. Dept. of Health, 497 U.S. 261, 344 (1990) (Stevens dissenting).

308. Id. at 344 .

309. Id. at n. 15 . 
resuscitation and terminating it. ${ }^{310}$ Pope Pius XII noted that while one is both lawfully permitted to accept resuscitation, there is no obligation to be resuscitated. ${ }^{311}$ In addition, the court cited a statement issued by the Vatican, and approved by Pope John Paul II, on the "right to die."312 The Vatican rejected the view that a "right to die" means to die by one's own hands; rather, they asserted that the right to die means the right to a peaceful death with human and Christian dignity. ${ }^{313}$ The Vatican emphasized, however, that a person has the right to refuse treatment when it would lead to death: "When inevitable death is imminent in spite of the means used, it is permitted in conscience to take the decision to refuse forms of treatment that would only secure a precarious and burdensome prolongation of life." ${ }^{\prime 14}$ Finally, the court concluded:

[t]hese authorities are consistent with the Judeo-Christian-Muslim belief that there is an afterlife more desirable than the earthly one. To those who espouse that belief, it may seem more egregious to delay a natural death and the beginning of eternal life than to needlessly prolong an unnatural, artificially-maintained existence on earth. ${ }^{315}$

When a competent, terminally ill patient seeks to end his or her life with a physician's assistance, the state's interest in that life, which will soon expire of "natural causes," diminishes. ${ }^{316}$ At this point, the state's primary interest in preventing suicide is merely to advance a distinctly religious view of the sanctity of life. ${ }^{317}$ Such an effort should be viewed, as Justice Stevens pointed out in Cruzan, "as an effort to define life, rather than to protect it." 318 Similarly, in Glucksberg, the Supreme Court attempted to define life by relying on natural death as the delineating factor. ${ }^{319}$ These decisions permit state governments to prohibit physician-assisted suicide based on Christianity's view of death. Like the sovereignty that God has over human life, ${ }^{320}$ the state claims dominion over an individual's right to choose the circumstances of his or her death.

God claims ownership over people by limiting how they can die. Similarly, the government, restricts the means by which one can control his or her own death. By restricting a person from controlling his or her death, the government is controlling that person. The government's exclusion over a personal, bodily choice establishes a greater property interest over an individual than the individual has of himself or herself. This is similar to the ownership that God

310. Woods v. Commonwealth, 142 S.W.3d 24, 47 (Ky. 2004).

311. Id.

312. Id. at 48 .

313. Id.

314. Id. at $48-49$.

315. Id at 49 .

316. Previn, supra note 14, at 605.

317. Id.

318. Id.

319. Washington v. Glucksberg, 521 U.S. 702, 728 (1997).

320. Genesis 1:26-27. 

THE 49TH PARALLEL

claims with the same reasoning by cloaking the justification for control in the sanctity of life. Although the government may not kill a person without due process such as the death penalty, the government is still exerting a type of control that makes one's "self" subservient to the government.

\section{iii. Intent: The Doctrine of Double Effect}

U.S. courts distinguish physician-assisted suicide and refusing medical treatment based on the intent of the physician - what does the physician intend to happen when the physician complies with the patient's request? For example, the Supreme Court concluded that when a patient refuses medical treatment and the physician complies, the patient intends to be free from unwanted medical assistance, and the physician intends to respect that patient's autonomy. ${ }^{321}$ Alternatively, when a patient requests that a physician prescribe lethal medication, courts assert that the patient intends to die and the physician can only intend the patient's death. ${ }^{322}$ But are these the only two intentions a patient and physician can have in these situations?

U.S. courts use the doctrine of double effect to morally distinguish the right to refuse medical treatment and physician-assisted suicide. ${ }^{323}$ The doctrine of double effect means that a person is allowed to cause harm as an unintended but foreseeable side-effect so long as that person has good intentions, but a person is not allowed to cause harm as an unintended but foreseeable side-effect if that person has bad intentions. ${ }^{324}$ Applied to end-of-life issues, the doctrine of double effect is used to justify "the permissibility of an action that causes a serious harm, such as the death of a human being, as a side effect of promoting some good end. ${ }^{325}$ For example:

A doctor who intends to hasten the death of a terminally ill patient by injecting a large dose of morphine would act impermissibly because he intends to bring about the patient's death. However, a doctor who intended to relieve the patient's pain with that same dose and merely foresaw the hastening of the patient's death would act permissibly. ${ }^{326}$

So long as the doctor intends to relieve the patient's pain and death is a foreseeable consequence, the patient's death is morally permissible. If that doctor intends to cause the patient's death, the doctor's actions are morally impermissible. Vacco v. Quill parallels this logic. The Supreme Court stated that "a physician who withdraws, or honors a patient's refusal to begin, life-sustaining

321. Vacco v. Quill, 117 S. Ct. 2293, 2298 (1997) (Stevens concurring).

322. Id.

323. GoRSUCH, supra note 300, at 53-63.

324. Id. at 53 .

325. Alison McIntyre, Doctrine of Double Effect, Stanford Encyclopedia of Philosophy (Dec. 24, 2018), https://plato.stanford.edu/entries/double-effect/ [https://perma.cc/CAR9-LRZH].

326. Id. 
medical treatment purposefully intends, or may so intend, only to respect his patient's wishes ..." ${ }^{927}$ The Vacco Court continued that a physician who provides pain-relievers that may kill the patient has the "purpose and intent is or may be, only to ease [the] patient's pain." 328 Similarly, "[a] doctor who assists a suicide, however, 'must, necessarily and indubitably, intend primarily that the patient be made dead." ${ }^{\prime 329}$ The physician, in every single scenario provided by the court, presumes that the physician shares the patient's intent. If the physician affirmatively assists in the patient's suicide, both the physician and patient can only intend the patient's death.

Even if the physician and patient act affirmatively in the patient's suicide, the physician and patient can contemplate a different intent. The Canadian Supreme Court surmised that the patient could intend his or her own bodily autonomy. In Carter, the Canadian Supreme Court stated that refusing medical treatment and physician-assisted suicide are similar because the patient may not intend his or her death but instead intends to control the course of his or her life. ${ }^{330}$ In general, the patient decided what he or she wants to do with his or her body. The Canadian Supreme Court interpreted intent more generally concerning a patient's intent to make independent choices concerning his or her body rather than the intent to cause a certain outcome depending on the means used (e.g., refusing medical treatment means that the patient wants to be free from medical treatment and ingesting lethal medication means the patient wants to kill himself or herself). ${ }^{331}$

The intent to make personal decisions about one's body is related to the causation distinction between refusing medical treatment and physician-assisted suicide. Just like the patient who commits suicide regardless of the means used to achieve the death, the patient chooses generally to make independent decisions about his or her body. This perspective focuses on the autonomy of the patient for the patient to make decisions about his or her body. The patient is the agent who causes his or her own death by consenting to whatever means are used, regardless of the physician's role. Similarly, the patient's intent is all that matters because the patient decides how to die and not the physician. The physician's intent matters only when the physician violates the patient's consent (e.g., the physician kills the patient without the patient's consent). The common factor between these two examples are the decisions that flow from the patient.

Apart from its application, the doctrine of double effect has Christian origins. Although secular application exists, ${ }^{332}$ Justice Gorsuch stated that "the double effect doctrine's link to Christian moral teaching is undeniable . .."333 The doctrine of double effect originated in Christian teachings. Specifically, Thomas

327. Vacco v. Quill, 117 S. Ct. 2293, 2298 (1997) (Stevens concurring).

328. Id.

329. Id.

330. Carter v. Canada (Att'y General), [2015] 1 S.C.R. 331, at para. 68 (Can.).

331. Id.

332. See GoRSUCH, supra note 300 , at 55 (detailing secular application of the doctrine of double effect.)

333. Id. 

THE 49TH PARALLEL

Aquinas originally introduced the doctrine himself in his "Summa Theologica (IIII, Qu. 64, Art. 7)." 334 The doctrine of double effect distinguishes between morally permissible and impermissible outcomes by classifying which intentions and causes are good or bad. ${ }^{335}$ Moral theologians made certain assumptions to employ the doctrine of double effect- "the nature of sin, intentions and attitudes of the penitent, the pursuit of and possibility of perfection in the Christian life, the nature of good and evil actions, which actions are 'absolutely' or 'intrinsically' evil. .." ${ }^{336}$ But what is the source of these assumptions? They derive from Adam's original sin in defying God and what God designates is good or evil. ${ }^{337}$ However, this brings up Euthyphro's Dilemma which states, "Does God command this particular action because it is morally right, or is it morally right because God commands it?" ${ }^{338}$ If it is the former, it is still subjective. If it is the ladder-that it is morally right because God commands it - a morally objective way exists to determine what is morally right and not because God commands it. ${ }^{339}$ With its Christian roots and subjective assumptions underlying the doctrine of double effect, it cannot conclude what is morally or immorally permissible.

Based on the foregoing, the doctrine of double effect is an untenable approach to distinguishing intent between the right to refuse medical treatment and physician-assisted suicide. The patient and physician can have more than one intent, and the doctrine of double effect cannot be utilized to distinguish the two practices based on its subjective assumptions. ${ }^{340}$

\section{State Interests for United States and Canada}

The Glucksberg Court concluded that physician-assisted suicide was not a right protected in the history and traditions of the United States. As a result, the Court applied rational basis review to the physician-assisted-suicide ban which requires that the ban needs to be rationally related to legitimate government interests. ${ }^{341}$ These four state interests are preserving life, preventing suicide, safeguarding the integrity of the medical profession, and protecting innocent third

334. McIntyre, supra note 325.

335. Id.

336. See generally John Berkman, How Important is the Doctrine of Double Effect for Moral Theology? Contextualizing the Controversy, 3 CHRistian Bioethics 89, 91 (1997).

337. See Práce, supra note 53.

338. Michael W. Austin, Divine Command Theory, Internet Encyclopedia of Philosophy, https://www.iep.utm.edu/divine-c/\#H3 (last visited May 2, 2020) [https://perma.cc/YD7X-6Z22].

339. See generally Larry Alexander and Michael Moore, Deontological Ethics, STANFORD UNIVERSITY (Oct. 17, 2016), https://plato.stanford.edu/entries/ethics-deontological/\#Age CenDeoThe [https://perma.cc/RG9U-V7M9].

340. See Berkman, supra note 336.

341. Washington v. Glucksberg, 521 U.S. 702, 728 (1997). 
parties. ${ }^{342}$ Each of these interests were considered by the Glucksberg Court, and it held that each interest was sufficient to uphold Washington's physicianassisted-suicide ban. ${ }^{343}$ This part analyzes the legitimacy of each aforementioned interest to determine if the Glucksberg Court properly weighed each interest against the physician-assisted-suicide ban.

\section{a. Preserving Life and Preventing Suicide}

The Glucksberg Court found that Washington has an unqualified interest in the preservation of human life. ${ }^{344}$ Washington's interest is forwarded in its criminal homicide statute: "The interests in the sanctity of life that are represented by the criminal homicide laws are threatened by one who expresses a willingness to participate in taking the life of another . . .." ${ }^{\prime 34}$ Similarly, the New Jersey Supreme Court recognized the state's interest in preserving the sanctity of life. ${ }^{346}$ Additionally, Washington has an interest in reducing suicide because it is a public-health problem. ${ }^{347}$

The Canadian Supreme Court adopted an opposing view in that the sanctity of life (embedded in section 7) does not need to be preserved at all costs. ${ }^{348}$ If the sanctity of life were to outweigh an individual's right to physician-assisted suicide, this would create a "duty to live" rather an "a right to life." 349 The court reasoned that it would call into question the right to refuse medical treatment in circumstances that would result in death. ${ }^{350}$ Applying this reasoning to Glucksberg, prioritizing Washington's interest in the sanctity of life creates a similar right to life. If Washington relies on the sanctity of life when prohibiting physician-assisted suicide, why should it not rely on it to ban the right to refuse medical treatment? The state's interest in limiting suicide is also called into question because the state relies on an arbitrary view of the sanctity of life. Moreover, Washington fails to further its interest in limiting suicide by directly banning the act.

The state's interest in the sanctity of life is rooted in Christianity. The sanctity of human life is couched in the belief that life is sacred because it originates from God. ${ }^{351}$ Similarly, Thomas Aquinas believed in the basic Christian tenet that committing suicide is against self-preservation. ${ }^{352}$ Committing suicide rejects

342. In re Conroy, 98 N.J. 321, 348-49 (1985).

343. Glucksberg, 521 U.S. at 735.

344. Id. at 728 .

345. Id. at 728-29.

346. In re Quinlan, 70 N.J. 10, 40 (1976); In re Conroy, 98 N.J. 321, 349 (1985).

347. Glucksberg, 521 U.S. at 730.

348. Carter, [2015] 1 S.C.R. at para. 63.

349. Id.

350. $I d$.

351. Genesis 9:5-6.

352. Marzen et al., supra note 35. 
God's sovereignty and value in life. ${ }^{353}$ In citing to the sanctity of life as a state interest, courts actively incorporate Christian values into their decisions, and therefore, the subjective view cannot be said to outweigh an individual's right to physician-assisted suicide.

\section{b. Integrity of the Medical Profession}

The Glucksberg Court concluded that Washington has an interest in "protecting the integrity and ethics of the medical profession." 354 The Court stated that "the American Medical Association [("AMA")], like many other medical and physicians' groups, has concluded that 'physician-assisted suicide is fundamentally incompatible with the physician's role as healer." 3555 The medical profession's integrity could be implicated because physician-assisted suicide could undermine the trust in a physician-patient relationship and could blur the line between heal and harm. ${ }^{356}$

Like the AMA, the Canadian Supreme Court addressed similar considerations of the Canadian Medical Association. ${ }^{357}$ It must also be noted that the Canadian Supreme Court viewed the impact on physicians individually ${ }^{358}$ as opposed to the United States that viewed the general effect on the medical profession's integrity. ${ }^{359}$ The general effect that the AMA is concerned with is the increased distrust between the patient and the physician. ${ }^{360}$ More significantly, the Canadian Supreme Court concluded that physicians would not have to provide assistance in dying. ${ }^{361}$ Similarly, the Conroy Court determined that the medical profession's integrity would not be compromised because medical ethics do not require medical intervention in disease at all costs. ${ }^{362}$

Because physicians would not be required to aid in dying, their medical ethics would not be compromised whatsoever. When considering the right to physicianassisted suicide, it is not an obligation on the physician to provide death assistance to a dying patient. Instead, it is an agreement in which both parties consent - the patient consents to dying and the physician consents by either removing medical treatment or prescribing lethal medication. The Canadian Supreme Court found that changes in the physician-patient relationship following legalization of physician-assisted suicide "could prove to be neutral or for the

353. Ephesians 5:29.

354. Washington v. Glucksberg, 521 U.S. 702, 731 (1997).

355. Id.

356. Id.

357. Carter v. Canada (Att'y General), [2015] 1 S.C.R. 331, at para. 131 (Can.).

358. Id. at para. 132 .

359. Glucksberg, 521 U.S. at 731.

360. Id.

361. Carter, [2015] 1 S.C.R. at para. 131.

362. In re Conroy, 98 N.J. 321, 351-52 (1985). 
good [of the patient]." ${ }^{933}$

\section{c. Protecting Innocent Third-Parties}

The Glucksberg Court concluded, "[Washington] has an interest in protecting vulnerable groups - including the poor, the elderly, and disabled people-from abuse, neglect, and mistakes." ${ }^{\text {" }} 34$ The interest extends to "protecting disabled and terminally ill people from prejudice, negative and inaccurate stereotypes, and societal indifference. ${ }^{1365}$ The Court reasoned that all groups should be treated equally. ${ }^{366}$ The physician-assisted-suicide ban should be applied to all groups of people and all suicide attempts and impulses should be interpreted equally. ${ }^{367}$

The Canadian Supreme Court agreed with the U.S. Supreme Court that the state has an interest in protecting the vulnerable from being induced to commit suicide and a total ban on physician-assisted suicide would help achieve this interest. ${ }^{368}$ However, the Canadian Supreme Court concluded that the ban was overbroad and includes individuals who wish to commit physician-assisted suicide and that "there may be people with disabilities who have a considered rational and persistent wish to end their own lives." ${ }^{" 369}$ As a result, the interest of protecting innocent third-parties is overbroad and prevents people with terminal illnesses from ending their own lives. To limit the vulnerability of third parties, safeguards could be implemented to ensure that no "coercion, undue influence, and ambivalence" are present during the decision-making process. ${ }^{370}$ Also, informed consent should be applied to physician-assisted suicide to "ensure a patient is properly informed of her diagnosis and prognosis. ${ }^{371}$

\section{IMPROVING U.S. CONSTITUTIONAL ANALYSIS}

The analysis of the Due Process Clause can be improved by relying on similar reasoning from the Canadian Supreme Court. Although the clauses are interpreted, conceived, and phrased differently, similarities offer instructive means to help improve substantive-due-process analysis under the Fourteenth Amendment. Under substantive due process, both prongs can be improved based on the U.S. view of the right to refuse medical treatment and the Supreme Court of Canada's consistent logical reasoning of physician-assisted suicide.

For the first prong, when looking through the history and traditions of the U.S., the analysis should not be limited to the mere history and status of the law.

363. Carter, [2015] 1 S.C.R. at para. 26.

364. Washington v. Glucksberg, 521 U.S. 702, 731 (1997).

365. Id.

366. Id. at 732 .

367. Id. at 732 .

368. Carter v. Canada (Att'y General), [2015] 1 S.C.R. 331, at para. 84 (Can.).

369. Id. at para. 86 .

370. Id. at para. 27.

371. Id. at para. 83 . 
Instead, the right to physician-assisted suicide must be derived from the right to informed consent, similar to Canada. The Supreme Court of Canada rejected the approach to natural death and reasoned that the distinction was untenable given that rejection of autonomy under assisted suicide would call into question the legality of refusing medical treatment. ${ }^{372}$ The Vacco Court adopted a natural death view, ${ }^{373}$ but as analyzed earlier, differentiating between cause and intent is illogical. ${ }^{374}$ Rather, U.S. courts need to reject the distinction between physicianassisted suicide and the right to reject medical treatment, and adopt an analysis of autonomy, bodily security, and informed consent. Under this approach, this would establish that a right to physician-assisted suicide that is constitutionally protected by the Due Process Clause of the Fourteenth Amendment.

As a result, courts that analyze government legislation infringing on physician-assisted suicide would apply a strict scrutiny standard, requiring that the law must be narrowly tailored to further a compelling government interest. For the second prong, states' interests in regulating physician-assisted suicide would have to be considerable to regulate the end-of-life practice. The strongest state interest was the sanctity or preservation of life. Such an interest derives from religious pretenses such as those espoused by the Puritans, Methodists, and other Christian beliefs. Generally, Christianity assumes that because God creates humans in his image, humans must similarly die of the natural causes proscribed by God. Because natural death and the sanctity of life are based on Christianity, the state does not have a compelling interest to limit assisted suicide. Instead, the United States should follow similar reasoning in that, like Canada, autonomy of the patient would outweigh any sanctity of life interest and reject religious considerations against physician-assisted suicide.

\section{CONCLUSION}

This Note analyzes the practice of end-of-life decisions, their origins, and foundational religious beliefs in the U.S. and Canada. It lays out the constitutional tests used in the U.S. and Canadian constitutions to analyze these end-of-life decisions. It then highlights shrouded, secular reasoning that U.S. courts used to distinguish physician-assisted suicide and the right to refuse medical treatment - action-inaction, cause, and intent — and utilizes the Canadian Supreme Court's reasoning to break down the fallacious decisions that the U.S. Supreme Court issued. This Note argues that the U.S. Supreme Court used religious appeals to differentiate between physician-assisted suicide and the right to refuse medical treatment - an appeal to the history of laws banning physician-assisted suicide; a cause-based natural death distinction relying on the sanctity of life; and the doctrine of double effect and its subjective assumptions of good and evil. As a result, this end-of-life distinction should not stand. Finally, this Note argues

372. Id. at para. 66-67.

373. Vacco v. Quill, 117 S. Ct. 2293, 2308 (1997) (Stevens concurring).

374. See supra Part III.C.1.c.ii-iii. 
that, in the U.S., states' interests are insufficient to outweigh an individual's interest in physician-assisted suicide as informed with criticisms from the Canadian Supreme Court.

An objective, logical justification for differentiating between physicianassisted suicide and refusing medical treatment has yet to be articulated in U.S. jurisprudence. Instead, this Note argues that the justification for both prongs of substantive due process have a religious basis, which invalidates bans on physician-assisted suicide. In fact, based on the foregoing, a right to physicianassisted suicide should be protected under the Due Process Clause of the Fourteenth Amendment. Canada's section 7 analysis is helpful to inform the U.S. constitutional analysis based on their similarities. Also, the United States has a foundation of informed consent, like Canada, to justify the right to refuse medical treatment, which could also be applied to the physician-assisted-suicide analysis in the U.S. Finally, to reduce state concerns such as preventing suicide and protecting the integrity of the medical profession and innocent third-parties, governments could introduce reasonable regulations on the administration of physician-assisted suicide to limit access and to ensure safe administration. By following the objective, constitutional analysis provided by the Canadian Supreme Court, the U.S. Supreme Court can adopt consistent legal reasoning, reject religious influence, and recognize a sensitive end-of-life decision for terminally ill patients to control their final moments. 